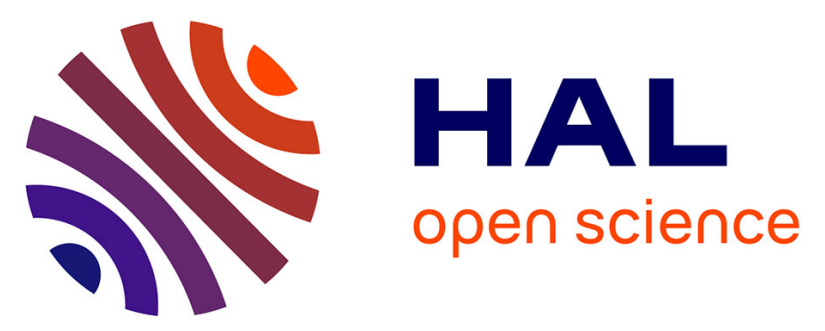

\title{
Two-dimensional Dion-Jacobson Hybrid Lead Iodide Perovskites with Aromatic Diammonium Cations
}

Xiaotong Li, Weijun Ke, Boubacar Traoré, Peijun Guo, Ido Hadar, Mikael Kepenekian, Jacky Even, Claudine Katan, Constantinos C Stoumpos, Richard Schaller, et al.

\section{To cite this version:}

Xiaotong Li, Weijun Ke, Boubacar Traoré, Peijun Guo, Ido Hadar, et al.. Two-dimensional DionJacobson Hybrid Lead Iodide Perovskites with Aromatic Diammonium Cations. Journal of the American Chemical Society, 2019, 141 (32), pp.12880-12890. 10.1021/jacs.9b06398 . hal-02187417

\section{HAL Id: hal-02187417 https://hal.science/hal-02187417}

Submitted on 16 Dec 2019

HAL is a multi-disciplinary open access archive for the deposit and dissemination of scientific research documents, whether they are published or not. The documents may come from teaching and research institutions in France or abroad, or from public or private research centers.
L'archive ouverte pluridisciplinaire HAL, est destinée au dépôt et à la diffusion de documents scientifiques de niveau recherche, publiés ou non, émanant des établissements d'enseignement et de recherche français ou étrangers, des laboratoires publics ou privés. 


\title{
Two-dimensional Dion-Jacobson Hybrid Lead Iodide Perovskites with Aromatic Diammonium Cations
}

Xiaotong Li, ${ }^{\dagger}$ Weijun Ke, ${ }^{\dagger}$ Boubacar Traoré,, Peijun Guo,${ }^{\ddagger}$ Ido Hadar, ${ }^{\dagger}$ Mikaël Kepenekian,${ }^{\S}$ Jacky Even," Claudine Katan, ${ }^{\S}$ Constantinos C. Stoumpos, ${ }^{\nabla}$ Richard D. Schaller, ${ }^{\dagger}, \downarrow$ and Mercouri G. Kanatzidis ${ }^{*} \dagger$

†Department of Chemistry, Northwestern University, 2145 Sheridan Road, Evanston, Illinois 60208, United States

†enter for Nanoscale Materials, Argonne National Laboratory, 9700 South Cass Avenue, Lemont, Illinois 60439, United States

"Univ Rennes, INSA Rennes, CNRS, Institut FOTON, UMR 6082, Rennes F-35000, France

§Univ Rennes, ENSCR, INSA Rennes, CNRS, ISCR (Institut des Sciences Chimiques de Rennes), UMR 6226, Rennes F-35000, France

$\nabla$ Department of Materials Science and Technology, Voutes Campus, University of Crete, Heraklion GR-70013, Greece

\begin{abstract}
Two-dimensional (2D) halide perovskites have extraordinary optoelectronic properties and structural tunability. Among them, the Dion-Jacobson phases with the inorganic layers stacking exactly on top of each other are less explored. Herein, we present the new series of 2D DionJacobson halide perovskites, which adopt the general formula of $A^{\prime} A_{n-1} P_{n} I_{3 n+1}\left(A^{\prime}=4\right.$ (aminomethyl)pyridinium (4AMPY), $\mathrm{A}=$ methylammonium (MA), $\mathrm{n}=1-4$ ). By modifying the position of the $-\mathrm{CH}_{2} \mathrm{NH}_{3}{ }^{+}$group from 4AMPY to $3 \mathrm{AMPY}$ (3AMPY = 3(aminomethyl)pyridinium), the stacking of the inorganic layers changes from exactly eclipsed to slightly offset. The perovskite octahedra tilts are also different between the two series, with the 3AMPY series exhibiting smaller bandgaps than the 4AMPY series. Compared to the aliphatic cation of the same size $(\mathrm{AMP}=($ aminomethyl)piperidinium $)$, the aromatic spacers increase the rigidity of the cation, reduce the interlayer spacing and decrease the dielectric mismatch between inorganic layer and the organic spacer, showing the indirect but powerful influence of the organic cations on the structure and consequently on the optical properties of the perovskite materials. All $A^{\prime} \mathrm{A}_{\mathrm{n}-1} \mathrm{~Pb}_{\mathrm{n}} \mathrm{I}_{3 \mathrm{n}+1}$ compounds exhibit strong photoluminescence (PL) at room temperature. Preliminary solar cell devices based on the $n=4$ perovskites as absorbers of both series exhibit promising performances, with a champion power conversion efficiency (PCE) of $9.20 \%$ for (3AMPY)(MA) ${ }_{3} \mathrm{~Pb}_{4} \mathrm{I}_{13}$ based devices, which is higher than the (4AMPY)(MA) ${ }_{3} \mathrm{~Pb}_{4} \mathrm{I}_{13}$ and the corresponding aliphatic analogue (3AMP)(MA) $)_{3} \mathrm{~Pb}_{4} \mathrm{I}_{13}$ based ones.
\end{abstract}


Keywords: halide perovskites, natural quantum-wells, photoluminescence, dielectric constant, exciton binding energy, solar cell devices.

\section{Introduction}

Hybrid halide perovskites are spectacular semiconducting materials suitable for a wide range of applications spanning photovoltaic devices ${ }^{1-3}$ to light emission ${ }^{4-6}$, detection ${ }^{7-8}$ and lasing ${ }^{9-10}$. The most extensively studied three-dimensional (3D) perovskites are of the general formula $\mathrm{AMX}_{3}(\mathrm{~A}$ $=\mathrm{Cs}^{+}, \mathrm{CH}_{3} \mathrm{NH}_{3}{ }^{+}(\mathrm{MA})$, or $\left.\mathrm{HC}\left(\mathrm{NH}_{2}\right)_{2}{ }^{+}(\mathrm{FA}) ; \mathrm{M}=\mathrm{Ge}^{2+}, \mathrm{Sn}^{2+}, \mathrm{Pb}^{2+} ; \mathrm{X}=\mathrm{Cl}^{-}, \mathrm{Br}^{-}, \mathrm{I}^{-}\right)$, where only three A-site cations can maintain the corner-sharing inorganic framework. ${ }^{11-12}$ For a larger cation to be incorporated into the structure, the 3D structures need to be broken down to lower dimensional structures, such as hollow perovskites (represented by (en) $\mathrm{AMX}_{3}{ }^{13-14}$, (hea) $\mathrm{AMX}_{3}{ }^{15}$ and (tea) $\mathrm{AMX}_{3}{ }^{16}$; en= ethylenediamonium, hea $=$ hydroxyethylammonium, tea = thioethylammonium) and two-dimensional (2D) structures with even larger organic cations intercalated between the inorganic layers acting as spacers. ${ }^{17-20}$ The $2 \mathrm{D}$ perovskites have also shown promising performance in solar cells ${ }^{21-23}$ and light emitting diodes (LEDs) ${ }^{24-28}$ with their main attribute being the exceptional stability, which derives from their water repellent nature and lower ion migration, as well as optoelectronic tunability. The most common members of this class are the (100)-oriented perovskites, with the large spacers "cleaving" the parent 3D perovskites along the (100) plane. ${ }^{17-20}$ Therefore, $2 \mathrm{D}$ perovskites can be regarded as naturally formed quantumwell systems, with the organic spacer serving as the barrier and the inorganic layer as the well, where the height of the barrier can be tuned by the dielectric constant of the organic spacer. ${ }^{19}$ Among the (100)-oriented 2D halide perovskites, four different types have been experimentally observed and characterized. These are Ruddlesden-Popper (RP) phase $\mathrm{A}_{2}{ }_{2} \mathrm{~A}_{\mathrm{n}-1} \mathrm{M}_{\mathrm{n}} \mathrm{X}_{3 \mathrm{n}+1}{ }^{29}$, Dion-Jacobson (DJ) phase $\mathrm{A}^{\prime} \mathrm{A}_{\mathrm{n}-1} \mathrm{M}_{\mathrm{n}} \mathrm{X}_{3 \mathrm{n}+1}{ }^{30}$, alternating cations ( $\mathrm{A}$ and $\mathrm{A}^{\prime}$ ) in the interlayer space (ACI) type $\mathrm{A}^{\prime} \mathrm{A}_{\mathrm{n}} \mathrm{M}_{\mathrm{n}} \mathrm{X}_{3 \mathrm{n}+1}{ }^{31-32}$, and those based on alkyl diammonium cations (DC) $\left(\mathrm{NH}_{3} \mathrm{C}_{\mathrm{m}} \mathrm{H}_{2 \mathrm{~m}} \mathrm{NH}_{3}\right)\left(\mathrm{CH}_{3} \mathrm{NH}_{3}\right)_{\mathrm{n}-1} \mathrm{~Pb}_{\mathrm{n}} \mathrm{I}_{3 \mathrm{n}+1}{ }^{33}$. The RP phases feature monovalent cations that can easily interdigitate between adjacent inorganic layers, enforcing a staggered arrangement where the stacked layers are shifted with respect to each other by half a unit cell (1/2, 1/2 displacements). This class dominates the 2D perovskites family in terms of known member-numbers. The DJ phases feature short divalent +2 cations between the layers which yield an eclipsed stacking arrangement (0, 0 displacements). The DJ phases are newly-reported halide perovskites, ${ }^{30}$ with 
only a few known examples ${ }^{34-37}$, most of them lacking proper structural characterization, especially for $n>2$ members. In the case of linear alkyl diammonium cations (DC), if the chain is sufficiently long, they tend to form staggered structures with the long chain adopting a canted orientation between the inorganic sheets. ${ }^{33}$ Even when the chain is as short as four carbons, the inorganic layers are still slightly offset, often with the octahedra distorted out-of-plane because of strong hydrogen-bonding. ${ }^{38}$ Moving from linear diammonium cations to short cyclic diammonium cations, e.g. $\mathrm{x}$-(aminomethyl)piperidinium (AMP) $(\mathrm{x}=3$ and 4$)$, DJ phases are favored as the distance between the inorganic layers becomes smaller. ${ }^{30}$ This observation raises questions: What other types of cations can template the DJ phase? And when the DJ phases are obtained, how do the different cations such as conformation, the presence of conjugated groups etc. affect the properties of the semiconducting layers in these materials?

In this work, we examine the aromatic analogues to the piperidinium cations, namely 3(aminomethyl)pyridinium (3AMPY) and 4-(aminomethyl)pyridinium (4AMPY), to synthesize two series of compounds, $(x A M P Y)(M A)_{n-1} P b_{n} I_{3 n+1}(x=3$ or $4, n=1-4)$. We hypothesized that the introduction of an aromatic ring in place of the aliphatic one of the same size will introduce new features such as a rise in the dielectric constant of the interlayer space, an increase in the rigidity of the cation, and more delocalization of the positive charge on the aromatic ring. These attributes can modulate the strength of the electrostatic interaction within the inorganic layers and the hydrogen-bonding to the surrounding, leading to a different structural distortion of the inorganic layers than those formed from the aliphatic AMP cations. All these allow for the finetuning of the electronic properties of the inorganic layers. We have successfully synthesized and solved the crystal structures of eight new members, namely (3AMPY)(MA) $)_{n-1} \mathrm{~Pb}_{n} \mathrm{I}_{3 n+1}(\mathrm{n}=1-4)$ and (4AMPY)(MA $)_{n-1} \mathrm{~Pb}_{\mathrm{n}} \mathrm{I}_{3 \mathrm{n}+1}(\mathrm{n}=1-4)$. We find structural differences between the 4AMPY and 3 AMPY analogues: only the more symmetric 4AMPY cation maintains the DJ structure $(0,0$ displacements), while in the crystal structures with 3AMPY the inorganic layers are slightly offset $(0.238,0.238$ displacements). The structural difference has a profound influence on the optical properties of the compounds, with reduced tilts of the perovskite octahedra for 3AMPY compounds resulting in smaller bandgaps than for the 4AMPY ones. We also find structural differences between the XAMPY and XAMP systems. Relative to the aliphatic XAMP systems, the XAMPY C-C bonds are shorter because of the aromaticity of the pyridine ring, and they bring the inorganic layers even closer to one another $(<4 \AA)$. Another feature caused by the aromatic cations 
is a decrease in the exciton binding energy which is attributed to the increased dielectric constant. Taking all these factors into consideration, we also fabricated preliminary solar cell devices using the $n=4$ members as solar absorbers. The device based on ( $3 A M P Y)(M A)_{3} \mathrm{~Pb}_{4} \mathrm{I}_{13}$ showed superior photovoltaic performance compared to the devices based on (4AMPY)(MA) ${ }_{3} \mathrm{~Pb}_{4} \mathrm{I}_{13}$ and the aliphatic analogue (3AMP)(MA) $)_{3} \mathrm{~Pb}_{4} \mathrm{I}_{13}$.

\section{Experimental Section}

Starting Materials $\mathrm{PbO}$ (99.9\%), methylamine hydrochloride (98\%), hydroiodic acid (57 wt \% in $\mathrm{H}_{2} \mathrm{O}$, distilled, stabilized, 99.95\%), and hypophosphorous acid solution (50 wt \% in $\left.\mathrm{H}_{2} \mathrm{O}\right)$, 3(aminomethyl)pyridine (99\%) and 4-(aminomethyl)pyridine (98\%) were purchased from SigmaAldrich and used as received.

(3AMPY)PbI $4.0 .5 \mathrm{mmol}$ (111.6 mg) $\mathrm{PbO}$ was dissolved in $2.5 \mathrm{~mL}$ concentrated aqueous $\mathrm{HI}$ solution under heating and vigorous stirring until a clear yellow solution was obtained. The temperature of the hot plate was set to $240{ }^{\circ} \mathrm{C}$ to keep the HI solution boiling at its boiling point $\left(127^{\circ} \mathrm{C}\right) .0 .5 \mathrm{mmol}(50.8 \mu \mathrm{L}) 3$-(aminomethyl)pyridine (3AMPY) was added to $0.5 \mathrm{~mL}$ of concentrated aqueous $\mathrm{H}_{3} \mathrm{PO}_{2}$ solution in a separate vial under stirring. The neutralized $3 \mathrm{AMPY}$ solution was added to the boiling HI solution under vigorous stirring and was further homogenized by stirring for $5 \mathrm{~min}$. Then the temperature was lowered to $120^{\circ} \mathrm{C}$ until red plate-shaped crystals started to precipitate out. Further decrease of the temperature to $80^{\circ} \mathrm{C}$ resulted in precipitation of most of the crystals within an hour. Then the hot plate was turned off and the solution was cooled slowly to room temperature. The whole process is conducted in air. After $30 \mathrm{~min}$, the product settled in the bottom of the vial and was isolated by suction filtration followed by drying on the filtration funnel for a further $30 \mathrm{~min}$. Yield: $279.5 \mathrm{mg}, 67.8 \%$ based on total $\mathrm{Pb}$.

(3AMPY)(MA)Pb ${ }_{2} \mathrm{I}_{7} .2 \mathrm{mmol}(446.4 \mathrm{mg}) \mathrm{PbO}$ and $1 \mathrm{mmol} \mathrm{CH}_{3} \mathrm{NH}_{3} \mathrm{Cl}(67.5 \mathrm{mg})$ were dissolved in $2.75 \mathrm{~mL}$ concentrated aqueous HI solution under heating and vigorous stirring until a clear yellow solution was obtained. The temperature of the hot plate was set to $240{ }^{\circ} \mathrm{C}$ to keep the HI solution boiling at its boiling point $\left(127^{\circ} \mathrm{C}\right) .0 .7 \mathrm{mmol}(71.2 \mu \mathrm{L}) 3 \mathrm{AMPY}$ was added to $0.5 \mathrm{~mL}$ of concentrated aqueous $\mathrm{H}_{3} \mathrm{PO}_{2}$ solution in a separate vial under stirring. The neutralized 3AMPY solution was added to the boiling HI solution under vigorous stirring and was further homogenized by stirring for $5 \mathrm{~min}$. Then the temperature was lowered to $120{ }^{\circ} \mathrm{C}$ until dark red plate-shaped crystals started to precipitate out. Further decrease of the temperature to $80{ }^{\circ} \mathrm{C}$ resulted in precipitation of most of the crystals within an hour. Then the hot plate was turned off and the 
solution was cooled slowly to room temperature. After $30 \mathrm{~min}$, the product settled in the bottom of the vial and was isolated by suction filtration followed by drying on the filtration funnel for a further $30 \mathrm{~min}$. Yield: $486.3 \mathrm{mg}, 33.7 \%$ based on total $\mathrm{Pb}$.

$(3 A M P Y)(M A)_{2} \mathrm{~Pb}_{3} I_{10} .1 .5 \mathrm{mmol}(334.8 \mathrm{mg}) \mathrm{PbO}$ and $1 \mathrm{mmol} \mathrm{CH}_{3} \mathrm{NH}_{3} \mathrm{Cl}$ (67.5 mg) were dissolved in $2.25 \mathrm{~mL}$ concentrated aqueous HI solution under heating and vigorous stirring until a clear yellow solution was obtained. The temperature of the hot plate was set to $240{ }^{\circ} \mathrm{C}$ to keep the HI solution boiling at its boiling point $\left(127^{\circ} \mathrm{C}\right) .0 .2 \mathrm{mmol}(20.3 \mu \mathrm{L}) 3 \mathrm{AMPY}$ was added to $0.5 \mathrm{~mL}$ of concentrated aqueous $\mathrm{H}_{3} \mathrm{PO}_{2}$ solution in a separate vial under stirring. The neutralized $3 \mathrm{AMPY}$ solution was added to the boiling HI solution under vigorous stirring and was further homogenized by stirring for $5 \mathrm{~min}$. Then the temperature was lowered to $120^{\circ} \mathrm{C}$ until black plate-shaped crystals started to precipitate out. Further decrease of the temperature to $80^{\circ} \mathrm{C}$ resulted in precipitation of most of the crystals within an hour. Then the hot plate was turned off and the solution was cooled slowly to room temperature. After $30 \mathrm{~min}$, the product settled in the bottom of the vial and was isolated by suction filtration followed by drying on the filtration funnel for a further $30 \mathrm{~min}$. Yield: $275.4 \mathrm{mg}, 26.7 \%$ based on total $\mathrm{Pb}$.

(3AMPY)(MA) ${ }_{3} \mathrm{~Pb}_{4} \mathrm{I}_{13} .2 \mathrm{mmol}(446.4 \mathrm{mg}) \mathrm{PbO}$ and $1.5 \mathrm{mmol} \mathrm{CH}_{3} \mathrm{NH}_{3} \mathrm{Cl}$ (101.3 mg) were dissolved in $3.25 \mathrm{~mL}$ concentrated aqueous HI solution under heating and vigorous stirring until a clear yellow solution was obtained. The temperature of the hot plate was set to $240{ }^{\circ} \mathrm{C}$ to keep the $\mathrm{HI}$ solution boiling at its boiling point $\left(127^{\circ} \mathrm{C}\right) .0 .15 \mathrm{mmol}(15.3 \mu \mathrm{L}) 3 \mathrm{AMPY}$ was added to 0.5 $\mathrm{mL}$ of concentrated aqueous $\mathrm{H}_{3} \mathrm{PO}_{2}$ solution in a separate vial under stirring. The neutralized 3AMPY solution was added to the boiling HI solution under vigorous stirring and was further homogenized by stirring for $5 \mathrm{~min}$. Then the temperature was lowered to $120^{\circ} \mathrm{C}$ until black plateshaped crystals started to precipitate out. Further decrease of the temperature to $80{ }^{\circ} \mathrm{C}$ resulted in precipitation of most of the crystals within an hour. Then the hot plate was turned off and the solution was cooled slowly to room temperature. After $30 \mathrm{~min}$, the product settled in the bottom of the vial and was isolated by suction filtration followed by drying on the filtration funnel for a further $30 \mathrm{~min}$. Yield: $179.0 \mathrm{mg}, 13.3 \%$ based on total $\mathrm{Pb}$.

(4AMPY)PbI $4.0 .5 \mathrm{mmol}(111.6 \mathrm{mg}$ ) $\mathrm{PbO}$ was dissolved in $2 \mathrm{~mL}$ concentrated aqueous HI solution under heating and vigorous stirring until a clear yellow solution was obtained. The temperature of the hot plate was set to $240{ }^{\circ} \mathrm{C}$ to keep the $\mathrm{HI}$ solution boiling at its boiling point $\left(127^{\circ} \mathrm{C}\right) .0 .5$ mmol $(50.7 \mu \mathrm{L}) 4$-(aminomethyl)pyridine (4AMPY) was added to $0.4 \mathrm{~mL}$ of concentrated aqueous 
$\mathrm{H}_{3} \mathrm{PO}_{2}$ solution in a separate vial under stirring. The neutralized 4AMPY solution was added to the boiling HI solution under vigorous stirring and was further homogenized by stirring for $5 \mathrm{~min}$. Then the temperature was lowered to $120{ }^{\circ} \mathrm{C}$ until orange plate-shaped crystals started to precipitate out. It is worth noting that light yellow precipitate came out during cooling down and suction filtration, so no pure phase was successfully isolated. This occurred even when filtering the solution while hot $\left(120^{\circ} \mathrm{C}\right)$.

(4AMPY)(MA)Pb ${ }_{2} \mathrm{I}_{7} .2 \mathrm{mmol}$ (446.4 mg) $\mathrm{PbO}$ and $1 \mathrm{mmol} \mathrm{CH}_{3} \mathrm{NH}_{3} \mathrm{Cl}$ (67.5 mg) were dissolved in $2.75 \mathrm{~mL}$ concentrated aqueous HI solution under heating and vigorous stirring until a clear yellow solution was obtained. The temperature of the hot plate was set to $240{ }^{\circ} \mathrm{C}$ to keep the HI solution boiling at its boiling point $\left(127^{\circ} \mathrm{C}\right) .0 .6 \mathrm{mmol}(60.8 \mu \mathrm{L}) 4 \mathrm{AMPY}$ was added to $0.5 \mathrm{~mL}$ of concentrated aqueous $\mathrm{H}_{3} \mathrm{PO}_{2}$ solution in a separate vial under stirring. The neutralized 4AMPY solution was added to the boiling HI solution under vigorous stirring and was further homogenized by stirring for $5 \mathrm{~min}$. Then the temperature was lowered to $120^{\circ} \mathrm{C}$ until red plate-shaped crystals started to precipitate out. Further decrease of the temperature to $80^{\circ} \mathrm{C}$ resulted in precipitation of most of the crystals within an hour. Then the hot plate was turned off and the solution was cooled slowly to room temperature. After $30 \mathrm{~min}$, the product settled in the bottom of the vial and was isolated by suction filtration followed by drying on the filtration funnel for a further $30 \mathrm{~min}$. Yield: $679.4 \mathrm{mg}, 47.0 \%$ based on total $\mathrm{Pb}$.

$(4 A M P Y)(M A)_{2} \mathrm{~Pb}_{3} \mathrm{I}_{10} .1 .5 \mathrm{mmol}(334.8 \mathrm{mg}) \mathrm{PbO}$ and $1 \mathrm{mmol} \mathrm{CH}_{3} \mathrm{NH}_{3} \mathrm{Cl}$ (67.5 mg) were dissolved in $2.5 \mathrm{~mL}$ concentrated aqueous HI solution under heating and vigorous stirring until a clear yellow solution was obtained. The temperature of the hot plate was set to $240{ }^{\circ} \mathrm{C}$ to keep the HI solution boiling at its boiling point $\left(127^{\circ} \mathrm{C}\right) .0 .25 \mathrm{mmol}(25.3 \mu \mathrm{L})$ 4AMPY was added to 0.5 $\mathrm{mL}$ of concentrated aqueous $\mathrm{H}_{3} \mathrm{PO}_{2}$ solution in a separate vial under stirring. The neutralized 4AMPY solution was added to the boiling HI solution under vigorous stirring and was further homogenized by stirring for $5 \mathrm{~min}$. Then the temperature was lowered to $120{ }^{\circ} \mathrm{C}$ until dark red plate-shaped crystals started to precipitate out. Further decrease of the temperature to $80{ }^{\circ} \mathrm{C}$ resulted in precipitation of most of the crystals within an hour. Then the hot plate was turned off and the solution was cooled slowly to room temperature. After $30 \mathrm{~min}$, the product settled in the bottom of the vial and was isolated by suction filtration followed by drying on the filtration funnel for a further $30 \mathrm{~min}$. Yield: $279.7 \mathrm{mg}, 27.1 \%$ based on total $\mathrm{Pb}$. 
(4AMPY)(MA) ${ }_{3} \mathrm{~Pb}_{4} I_{13} .2 \mathrm{mmol}(446.4 \mathrm{mg}) \mathrm{PbO}$ and $1.5 \mathrm{mmol} \mathrm{CH}_{3} \mathrm{NH}_{3} \mathrm{Cl}$ (101.3 mg) were dissolved in $3.25 \mathrm{~mL}$ concentrated aqueous HI solution under heating and vigorous stirring until a clear yellow solution was obtained. The temperature of the hot plate was set to $240{ }^{\circ} \mathrm{C}$ to keep the HI solution boiling at its boiling point $\left(127^{\circ} \mathrm{C}\right) .0 .14 \mathrm{mmol}(14.2 \mu \mathrm{L})$ 4AMPY was added to 0.5 $\mathrm{mL}$ of concentrated aqueous $\mathrm{H}_{3} \mathrm{PO}_{2}$ solution in a separate vial under stirring. The neutralized 4AMPY solution was added to the boiling HI solution under vigorous stirring and was further homogenized by stirring for $5 \mathrm{~min}$. Then the temperature was lowered to $120^{\circ} \mathrm{C}$ until black plateshaped crystals started to precipitate out. Further decrease of the temperature to $80{ }^{\circ} \mathrm{C}$ resulted in precipitation of most of the crystals within an hour. Then the hot plate was turned off and the solution was cooled slowly to room temperature. After $30 \mathrm{~min}$, the product settled in the bottom of the vial and was isolated by suction filtration followed by drying on the filtration funnel for a further $30 \mathrm{~min}$. Yield: $159.4 \mathrm{mg}, 11.9 \%$ based on total $\mathrm{Pb}$.

Single Crystal Structures. Single-crystal X-ray diffraction experiments were performed using a STOE IPDS II or IPDS 2T diffractometer with Mo K $\alpha$ radiation $(\lambda=0.71073 \AA)$ and operating at $50 \mathrm{kV}$ and $40 \mathrm{~mA}$. Integration and numerical absorption corrections were performed using the $\mathrm{X}$ AREA, X-RED, and XSHAPE programs. The structures were solved by charge flipping and refined by full-matrix least-squares on $\mathrm{F}^{2}$ using the Jana 2006 package. ${ }^{39}$ The PLATON ${ }^{40}$ software was used to identify the twinning domains and validate the space groups of the compounds.

Steady-State and Time-Resolved Photoluminescence. Steady-state PL spectra were collected using a HORIBA LabRAM HR Evolution confocal Raman microscope. $473 \mathrm{~nm}$ laser was used to excite the samples at 50× magnification. Time-resolved photoluminescence spectra were acquired with a streak camera (Hamamatsu). The samples were excited at $365 \mathrm{~nm}$ using an optical parametric amplifier, which was pumped by a Ti:sapphire amplifier operating at 800-nm and 2 $\mathrm{kHz}$ repetition rate. During the photoluminescence measurements, the samples were mounted in a closed-cycle vacuum cryostat under a pressure below $10^{-7}$ Torr. A $370 \mathrm{~nm}$ long pass filter was used before the detection to block the excitation light.

Device Fabrication. FTO glass substrates were coated with PEDOT:PSS by spin-coating at 4000 $\mathrm{rpm}$ for $30 \mathrm{~s}$, and then annealed at $150{ }^{\circ} \mathrm{C}$ for $30 \mathrm{~min}$ in air. The $2 \mathrm{D}$ perovskite precursors with a molar concentration of $0.8 \mathrm{M}$ were prepared by dissolving the $2 \mathrm{D}$ perovskite crystal powders in a mixed solvent of DMF and DMSO with a volume ratio of 4:1. After the crystal powders dissolved, 0.8 vol \% HI was added into the perovskite precursors. The precursors were then coated on the 
substrates with a spin rate of $4000 \mathrm{rpm}$ for $60 \mathrm{~s}$ in a $\mathrm{N}_{2}$-filled glovebox. During the spin-coating, $0.7 \mathrm{~mL}$ of diethyl ether was dropped on the rotating substrates at $20 \mathrm{~s}$. After spin-coating, the films were annealed at $100{ }^{\circ} \mathrm{C}$ for $10 \mathrm{~min}$ in the glovebox. To complete the devices, C60 (20 nm)/BCP $(5 \mathrm{~nm}) / \mathrm{Ag}(100 \mathrm{~nm})$ were sequentially thermally evaporated on top of the perovskites. The active area of the solar cells was $0.09 \mathrm{~cm}^{2}$.

Device Characterization. J-V curves were measured by a Keithley model 2400 instrument under AM1.5G simulated irradiation with a standard solar simulator (Abet Technologies). The light intensity of the solar simulator was calibrated by a National Renewable Energy Laboratorycertified monocrystalline silicon solar cell. EQE curves were measured by an Oriel model QE-PVSI instrument equipped with a National Institute of Standards and Technology certified Si diode.

\section{Results and Discussion}

Syntheses. The new compounds were synthesized using a step-cooling method as previously reported, ${ }^{33}$ with stoichiometric ratios of $\mathrm{PbO}$ and $\mathrm{CH}_{3} \mathrm{NH}_{3} \mathrm{Cl}$ according to the chemical formula. By tuning the amount of the large spacer cations, 3AMPY or 4AMPY, the synthetic procedure can be optimized to give different layer-numbers $(n=1-4)$ in a targeted manner. It is worth noting that for (4AMPY) $\mathrm{PbI}_{4}$, even though it can form in the hot solution, no pure phase could be obtained because a competing light-yellow phase co-crystallized on cooling to room temperature. To get one single crystal to determine the crystal structure, hot solution $\left(120^{\circ} \mathrm{C}\right)$ was dropped directly into oil and the crystal must be picked quickly (details in experimental section). All compounds form as plate-like crystals, with the color getting darker from $n=1$ to $n=4$. The 3AMPY series exhibits darker color than the 4AMPY series, starting from red for $n=1$ to black for $n=4$ while $n$ $=1$ for $4 \mathrm{AMPY}$ is orange.

The powder X-ray diffraction (PXRD) patterns of (4AMPY)(MA) $)_{n-1} \mathrm{~Pb}_{n} \mathrm{I}_{3 n+1}(\mathrm{n}=2-4)$ obtained using synchrotron radiation $(\lambda=0.4578 \AA)$ are shown in Figure 1 . The experimental patterns match well with the calculated ones and the low angle peaks are apparent for all (4AMPY)(MA) $)_{n-1} \mathrm{~Pb}_{\mathrm{n}} \mathrm{I}_{3 \mathrm{n}+1}$ $(n=2-4)$ materials, with the number of peaks below $2 \theta=4^{\circ}$ corresponding to the layer-number. ${ }^{29}$ The d-spacing of the first Bragg peak in the PXRD pattern corresponds to the stacking axis length of the unit cell for the primitive cells ( $\mathrm{a}$ axis for $\mathrm{n} \geq 2$ ), with $\mathrm{b} \approx \mathrm{c} \approx 8.8 \AA$.

Description of the Crystal Structures. In general, to be able to take full advantage of the optoelectronic properties of $2 \mathrm{D}$ perovskites as a function of organic spacer, precise structural 
information is needed for each compound. Because of the soft and flexible nature of the inorganic layer, the type of organic spacers may significantly influence its structural details. This can lead to additional control of the properties beyond the one afforded by controlling the composition and thickness of the layers themselves.

For the Ruddlesden-Popper (RP) phases, +1 cations are interdigitated between the inorganic layers, so the organic tail has the flexibility to move around. ${ }^{41}$ While for the Dion-Jacobson (DJ) phases, the gap is bridged by the short dications, which increase the rigidity of the structure and also bring the layers closer to each other. ${ }^{30}$ By replacing the aliphatic (aminomethyl)piperidinium (AMP) rings with more rigid aromatic (aminomethyl)pyridinium (AMPY) ones, the atoms of the cation have less freedom to move. Therefore, only the more symmetric 4AMPY series forms the proper DJ structure type (Figure 2), (4AMPY)(MA) $)_{n-1} \mathrm{~Pb}_{n} \mathrm{I}_{3 n+1}(\mathrm{n}=2-4)$, where the inorganic layers stack exactly on top of each other. The 3AMPY series, (3AMPY)(MA) $)_{n-1} \mathrm{~Pb}_{n} \mathrm{I}_{3 n+1}(\mathrm{n}=1-4)$, on the other hand, exhibits inorganic slabs that are slightly offset (Figure S2) (more details will be discussed below). Selected crystallographic information and structural refinements for the eight compounds are presented in Table 1, with detailed crystallographic data provided in the Supporting Information (Tables S1-S8).

The (4AMPY)(MA) $)_{n-1} \mathrm{~Pb}_{n} \mathrm{I}_{3 n+1}(\mathrm{n}=1-4)$ series is strictly DJ type and crystallize in monoclinic space groups. The polar space group is used because all the primary amino groups of the spacer cations are pointed to the same direction, resulting in a net dipole. Unlike the Ruddlesden-Popper phases which have two spacer cations between the layers and tend to cancel out the respective dipole moments, the Dion-Jacobson phases only have one polar +2 cation. So it is necessary to refine the structure in the non-centrosymmetric space groups. The a axis is the stacking axis, except for $\mathrm{n}=1$ (b-axis), and the length of the stacking axis follows the formula $\mathrm{a} \sim 6.3 \mathrm{n}+\mathrm{x} \AA,{ }^{29,33}$ where $\mathrm{n}$ is the layer-number and $\mathrm{x}$ is the distance between the inorganic layers. The inorganic perovskite layers have corner-sharing octahedra that stack exactly on top of each other (eclipsed conformation) being separated by the 4AMPY cations. The aromatic pyridinium ring is highly ordered and orients parallel to the stacking direction and adjacent cations adopt an edge-to-face interaction, ${ }^{42}$ with the aromatic planes almost perpendicular to each other (Figure 3b). This motif is also seen in 2D perovskites systems incorporating other aromatic cations. ${ }^{43-45}$ Because of the resonance of the aromatic ring, the ortho and para ( 2 and 4 ) positions are activated, bearing more partial positive charges. Then the partial positive charge is brought to the primary $\mathrm{NH}_{3}{ }^{+}$group through the 
inductive effect of the carbon in the aminomethyl group $\left(-\mathrm{CH}_{2} \mathrm{NH}_{3}{ }^{+}\right)$. This suggests that the ordered cation in the structure is stabilized by the strong electrostatic attraction between the organic and inorganic components, which is also confirmed by the shallower intrusion depth of the $\mathrm{CH}_{2} \mathrm{NH}_{3}{ }^{+}$groups into the grooves of the inorganic slab surface and smaller $\mathrm{NH}_{3}{ }^{+\cdots}$ I distances (see below). Besides, the hydrogen bonding between the N-H of the pyridinium ring and the bridging iodide of the $\left[\mathrm{PbI}_{6}\right]$ octahedra (Figure $4 \mathrm{~b}$ ) distorts the inorganic layers mainly parallel to the slab and barely perpendicular to it (Figure $3 b$ ).

As mentioned above, compared to the 4AMPY series, the perovskite layers in the 3AMPY structures are slightly offset, with the differences highlighted in Figure 3, showing that the positions of the functional groups play an essential role in defining the structural details. It is worth pointing out that the spacer cations in the 3AMPY series are disordered and they are modeled with restraints of bond lengths and angles. The difference between order and disorder in 4AMPY and 3AMPY, respectively, is nicely reflected in the refinement statistics, which are consistently better for the 4AMPY series. The $-\mathrm{CH}_{2} \mathrm{NH}_{3}{ }^{+}$group in the meta-position of the aromatic 3AMPY ring seems to be interacting loosely with the terminal iodine atoms (Figure 4a). Because of this, with 4AMPY the compound has a major distortion (equatorial $\mathrm{Pb}-\mathrm{I}-\mathrm{Pb}$ angle $153.9^{\circ}$ for $\mathrm{n}=2$ ) along the inorganic plane, whereas with 3AMPY the distortion is smaller and nearly isotropic (equatorial $\mathrm{Pb}-\mathrm{I}-\mathrm{Pb}$ angle $168.9^{\circ}$ and axial $\mathrm{Pb}-\mathrm{I}-\mathrm{Pb}$ angle $164.4^{\circ}$ for $\mathrm{n}=2$ ) (Figure $3 \mathrm{a}$ ). Furthermore, the rigidity of the aromatic system restricts the ring to planarity, so the inorganic layers are slightly staggered to accommodate the asymmetry of the 3AMPY cation.

The structure of the two dications and how they interact with the anion slabs may also influence the stacking. The positive ends of the dications interact with the perovskite slabs by intruding into the grooves formed by the terminal iodine atoms. The degree of intrusion is indicative of the strength of electrostatic interaction. The penetration depth of the ammonium group, defined by the distance between the primary $-\mathrm{NH}_{3}{ }^{+}$and the plane of terminal iodides (Figure $4 \mathrm{a}, \mathrm{b}$ ), is much larger for the 3 AMPY series ( $0.829 \AA$ compared to $0.584 \AA$ ), and the cation is tilted instead of lying parallel to the stacking axis. These structural details reveal that 3AMPY sinks deeper into the inorganic layer than 4AMPY. The closest $\mathrm{NH}_{3}{ }^{+\cdots}$ I distances are $3.902 \AA$ (terminal) and $3.718 \AA$ (bridge) for 3AMPY, $3.718 \AA$ (terminal) and $3.608 \AA$ (bridge) for 4AMPY (Figure 4a,b). This in turn shortens the distance between the inorganic slabs for the 3AMPY series compared to the 4AMPY series, as shown in Figure 4c. The distances between two inorganic layers are even 
smaller than the aliphatic AMP systems since the C-C bonds are shorter because of the $s p^{2}$ hybridization. However, since the slabs in the 3AMPY series are slightly offset, the closest direct I $\cdots$ I distance is still larger than that in the 4AMPY series, with the exception of $n=1$ (Figure $4 d$ ). As layer-number $n$ increases, the closest I $\cdots$ I distance slightly decreases for both series. The closer proximity of the inorganic layers may lead to slightly more dispersive bands in the corresponding direction in reciprocal space as reported in our previous work. ${ }^{30}$

It has been reported that the penetration depth has a correlation with the distortion level of the octahedra, which mainly influences the $\mathrm{Pb}-\mathrm{I}-\mathrm{Pb}$ angles. ${ }^{44}$ As the penetration depth increases, the distance between the $\mathrm{NH}_{3}{ }^{+}$and the nearest I also increase (Figure 4a,b), weakening electronic interaction and the hydrogen-bonding, and increasing the $\mathrm{Pb}-\mathrm{I}-\mathrm{Pb}$ angles. We classify the $\mathrm{Pb}-\mathrm{I}-\mathrm{Pb}$ angles into two categories, the equatorial angle (parallel to the inorganic plane) and the axial angle (in the stacking direction) (Figure 4b). For the DJ phase, the 4AMPY series is distorted mainly inplane (Figure $3 \mathrm{~b}$ ) and barely distorted out-of-plane, so the axial angle is close to $180^{\circ}$ (Figure $3 \mathrm{c}$ ). While the 3AMPY series is distorted both in-plane and out-of-plane (Figure 3a). Figure 3c-e shows a comparison of $\mathrm{Pb}-\mathrm{I}-\mathrm{Pb}$ angles for a collection of members. As the layer-number increases, the average $\mathrm{Pb}-\mathrm{I}-\mathrm{Pb}$ angles increase from $166.3^{\circ}$ to $167.9^{\circ}$ for the $3 \mathrm{AMPY}$ series and from $149.2^{\circ}$ to $163.2^{\circ}$ for the 4AMPY series (Figure $3 \mathrm{e}$ ). This suggests that as the inorganic layer grows thicker, the influence of the organic spacer decreases, especially for the 4AMPY series. However, both the equatorial (Figure 3d) and average $\mathrm{Pb}-\mathrm{I}-\mathrm{Pb}$ angles (Figure 3e) are consistently larger for all layernumbers of the 3AMPY series, which suggests the structure is less distorted than in 4AMPY analogues.

Optical properties. The absorption spectra (Figure 5a,c) of both series show a high-energy absorption edge and a lower-energy exciton peak. The bandgaps are estimated by extrapolating the high-energy slope to the imaginary axis parallel to the $\mathrm{x}$ axis where the absorption edge is interrupted by the exciton peak. ${ }^{29}, 33$ The spectra show that 3AMPY series exhibits consistently lower bandgaps than the 4AMPY materials. The bandgaps of the 3AMPY series decrease from $2.34 \mathrm{eV}$ to $1.87 \mathrm{eV}$ for $\mathrm{n}=1-4$, while those for the 4AMPY series decline from 2.15 to 1.89 for $\mathrm{n}$ $=2-4$ (Table 2). As discussed above, the 3AMPY series has larger Pb-I-Pb angles and thus smaller octahedral tilts, which means the $\mathrm{Pb}$ s- and I p-orbitals have better overlap resulting in a smaller bandgaps. ${ }^{46-47}$ 
Both series of compounds exhibit strong photoluminescence (PL) at room temperature (Figure 5b, d). Based on band structure calculations reported for the aliphatic xAMP series, ${ }^{30}$ these $2 \mathrm{D}$ perovskites, regardless of the thickness of the inorganic layers, are essentially direct bandgap semiconductors, which agrees well with our experimental results of sharp absorption edge and strong PL. The peak positions of the PL spectra follow the same trend as the bandgaps extracted from absorption spectra, with the peaks of the 3AMPY series showing up at lower energies. The PL lifetimes of both series fall in the range of $0.1-0.3 \mathrm{~ns}$ (Figure S3), which are comparable to the lifetimes of previously reported lead iodide 2D perovskites resulting predominantly from rapid exciton recombination. ${ }^{30,33,48}$ Interestingly, the PL lifetimes of the crystals of the 3AMPY series are longer than those of the 4AMPY series (Figure S3), which is an indication of slower carrier recombination and improved carrier transport.

To compare the optical properties of the 3AMPY and 4AMPY series with the previously reported aliphatic system $(\mathrm{xAMP})(\mathrm{MA})_{\mathrm{n}-1} \mathrm{~Pb}_{\mathrm{n}} \mathrm{I}_{3 \mathrm{n}+1}(\mathrm{x}=3$ or $4, \mathrm{AMP}=($ aminomethyl $)$ piperidinium $)$ and the Ruddlesden-Popper phases $(\mathrm{BA})_{2}(\mathrm{MA})_{\mathrm{n}-1} \mathrm{~Pb}_{\mathrm{n}} \mathrm{I}_{3 \mathrm{n}+1}(\mathrm{BA}=$ butylammonium), we plot the PL spectra for $\mathrm{n}=4$ together (Figure 6a,c). It is clear that the $(\mathrm{BA})_{2}(\mathrm{MA})_{3} \mathrm{~Pb}_{4} \mathrm{I}_{13}$ has the highest energy PL emission among the compounds, even though it is not the most distorted structure (Table 3). Therefore, there must be other factors that may influence the bandgaps besides the $\mathrm{Pb}-\mathrm{I}-\mathrm{Pb}$ angles as discussed above. In our previous work, we proposed that there is a correlation between the bandgap and the interlayer spacing: the closer the d-spacing, the stronger the interaction between the layers, and the smaller the bandgap. ${ }^{33}$ The PL emission peaks for (3AMPY) $2(\mathrm{MA})_{3} \mathrm{~Pb}_{4} \mathrm{I}_{13}$ and $(3 \mathrm{AMP})_{2}(\mathrm{MA})_{3} \mathrm{~Pb}_{4} \mathrm{I}_{13}$ are $0.1 \mathrm{eV}$ lower in energy than that of $(\mathrm{BA})_{2}(\mathrm{MA})_{3} \mathrm{~Pb}_{4} \mathrm{I}_{13}$ (Figure $\left.6 \mathrm{a}\right)$, even though they have similar average $\mathrm{Pb}-\mathrm{I}-\mathrm{Pb}$ angles (Table 3). Since the interlayer spacing for $(3 \mathrm{AMPY})_{2}(\mathrm{MA})_{3} \mathrm{~Pb}_{4} \mathrm{I}_{13}$ and $(3 \mathrm{AMP})_{2}(\mathrm{MA})_{3} \mathrm{~Pb}_{4} \mathrm{I}_{13}$ are below $4 \AA$, it makes sense that the interactions between the layers are slightly stronger, thus reducing the bandgaps.

For the $(4 \mathrm{AMPY})_{2}(\mathrm{MA})_{3} \mathrm{~Pb}_{4} \mathrm{I}_{13}$ and $(4 \mathrm{AMP})_{2}(\mathrm{MA})_{3} \mathrm{~Pb}_{4} \mathrm{I}_{13}$ (Figure $\left.6 \mathrm{c}\right)$, their PL peaks are in higher energies than the $(3 \mathrm{AMPY})_{2}(\mathrm{MA})_{3} \mathrm{~Pb}_{4} \mathrm{I}_{13}$ and $(3 \mathrm{AMP})_{2}(\mathrm{MA})_{3} \mathrm{~Pb}_{4} \mathrm{I}_{13}$ and much closer to that of $(\mathrm{BA})_{2}(\mathrm{MA})_{3} \mathrm{~Pb}_{4} \mathrm{I}_{13}$, because the more distorted structures counteract the bandgap reduction from the decrease of the interlayer distance: the $\mathrm{Pb}-\mathrm{I}-\mathrm{Pb}$ angles, especially the equatorial ones, are much smaller than those of $(\mathrm{BA})_{2}(\mathrm{MA})_{3} \mathrm{~Pb}_{4} \mathrm{I}_{13}$ (Table 3), so the $\mathrm{Pb}$ s- and I p-orbitals have less overlap, and overall the bandgaps are similar for $(4 \mathrm{AMPY})_{2}(\mathrm{MA})_{3} \mathrm{~Pb}_{4} \mathrm{I}_{13},(4 \mathrm{AMP})_{2}(\mathrm{MA})_{3} \mathrm{~Pb}_{4} \mathrm{I}_{13}$ and 
$(\mathrm{BA})_{2}(\mathrm{MA})_{3} \mathrm{~Pb}_{4} \mathrm{I}_{13}$. But the $\mathrm{Pb}-\mathrm{I}-\mathrm{Pb}$ angles still play a role when it comes to structures with similar interlayer spacing, e.g. (3AMPY $)_{2}(\mathrm{MA})_{3} \mathrm{~Pb}_{4} \mathrm{I}_{13}$ and $(4 \mathrm{AMPY})_{2}(\mathrm{MA})_{3} \mathrm{~Pb}_{4} \mathrm{I}_{13}$.

In addition to the differences in PL emission, there is also a change in the exciton binding energy when using aromatic spacer cations instead of the aliphatic ones. As shown in the absorption spectra in Figure 6b,d, even though the high-energy bandgap slopes look similar, the low-energy slopes vary because of the existence of exciton peaks, stable even at room temperature. We can roughly estimate the exciton binding energy $\left(\mathrm{E}_{\mathrm{b}}\right)$ by subtracting energy of the exciton peaks relative to the bandgaps, ${ }^{49}$ with the aromatic system showing smaller $\mathrm{E}_{\mathrm{b}}$ than the aliphatic system, which suggests that the electron-hole pairs are more easily separated and collected by the electron/hole transport layers in the photovoltaic devices. This is because the aromatic cation exhibits a larger dielectric constant $\left(\varepsilon_{\mathrm{b}} \sim 3\right)$ than the aliphatic barrier $\left(\varepsilon_{\mathrm{b}} \sim 2\right)$ owing to the existence of the delocalized $\pi$-electron cloud, ${ }^{50-53}$ thus reducing the dielectric mismatch, and the corresponding dielectric confinement effect in the naturally formed quantum-well structures. A more accurate comparison of exciton binding energy between different systems can be performed by low-temperature absorption spectroscopy ${ }^{51}$ and magnetoabsorption spectroscopy ${ }^{54-55}$.

Solar cell device performance. Given the promising optical properties, we proceeded to fabricate thin-films with the $n=4$ materials. We also compare the thin-film with the aliphatic cation $(3 \mathrm{AMP})(\mathrm{MA})_{3} \mathrm{~Pb}_{4} \mathrm{I}_{13}$ using the same film deposition method. In the PXRD patterns in Figure $7 \mathrm{a}$, (011) and (022) peaks at $\sim 14^{\circ}$ and $28^{\circ}$ dominate, indicating all films have vertically preferred orientation and good crystallinity. However, we observed that the (3AMPY)(MA) ${ }_{3} \mathrm{~Pb}_{4} \mathrm{I}_{13}$ film has the strongest peak intensity, which is about 5 times stronger than in $(3 \mathrm{AMP})(\mathrm{MA})_{3} \mathrm{~Pb}_{4} \mathrm{I}_{13}$. This indicates that the (3AMPY)(MA) ${ }_{3} \mathrm{~Pb}_{4} \mathrm{I}_{13}$ film has better layer orientation and crystallinity, leading to improved charge transport and enhanced charge collection. There is also a big difference on the PL lifetimes for the different films. As shown in Figure S4 and Table S9, the (3AMPY)(MA) ${ }_{3} \mathrm{~Pb}_{4} \mathrm{I}_{13}$ film has the longest average PL lifetime of $117.9 \mathrm{~ns}$ compared to $32.1 \mathrm{~ns}$ for (4AMPY)(MA) $)_{3} \mathrm{~Pb}_{4} \mathrm{I}_{13}$ film and $35.2 \mathrm{~ns}$ for $(3 \mathrm{AMP})(\mathrm{MA})_{3} \mathrm{~Pb}_{4} \mathrm{I}_{13}$ film, suggesting the lowest carrier recombination for $(3 \mathrm{AMPY})(\mathrm{MA})_{3} \mathrm{~Pb}_{4} \mathrm{I}_{13}$ film. The long lifetimes are a good indication of the high film-quality, usually high-quality films exhibit longer lifetimes than the corresponding crystals. We also examine the morphology of the films by scanning electron microscopy (SEM). As shown in Figure S5, the films are dense and smooth without pinholes, and the cross-sectional 
SEM images exhibit similar perovskite layer thickness for the films made with solution of the same concentration. The grain size of the films is also similar, around $100 \mathrm{~nm}$.

On the basis of these results, we made preliminary attempts to fabricate solar cell devices using the $\mathrm{n}=4$ perovskites as light absorbers. The devices were fabricated using the same device structure and deposition method as previously reported by our group, ${ }^{23,}{ }^{30}$ which also make the comparison between different systems possible. The photocurrent density-voltage $(J-V)$ curves of the representative devices based on the $\mathrm{n}=42 \mathrm{D}$ perovskites, (xAMPY)(MA) ${ }_{3} \mathrm{~Pb}_{4} \mathrm{I}_{13}(\mathrm{x}=3$ or 4$)$ and (3AMP)(MA) ${ }_{3} \mathrm{~Pb}_{4} \mathrm{I}_{13}$, reported here and previously ${ }^{30}$ are shown in Figure $7 \mathrm{c}$ for comparison. The (3AMPY)(MA) ${ }_{3} \mathrm{~Pb}_{4} \mathrm{I}_{13}$-based solar cell achieved the highest power conversion efficiency (PCE) of $9.20 \%$, with a short-circuit current density $\left(J_{\mathrm{sc}}\right)$ of $14.34 \mathrm{~mA} \mathrm{~cm}^{-2}$, an open-circuit voltage $\left(V_{\mathrm{oc}}\right)$ of $1.08 \mathrm{eV}$ and a fill factor $(\mathrm{FF})$ of 59.58\%. For comparison, the PCEs for the best devices based on the (4AMPY)(MA) $)_{3} \mathrm{~Pb}_{4} \mathrm{I}_{13}$ and (3AMP)(MA) $)_{3} \mathrm{~Pb}_{4} \mathrm{I}_{13}$ absorbers are $5.69 \%$ and $6.89 \%$, respectively (Table S10).

The (3AMPY)(MA) ${ }_{3} \mathrm{~Pb}_{4} \mathrm{I}_{13}$ cell has much higher $J_{\mathrm{sc}}$ than the other two, which is also verified by the external quantum efficiency (EQE) measurements (Figure 7d), where the (3AMPY)(MA) ${ }_{3} \mathrm{~Pb}_{4} \mathrm{I}_{13}$ solar cell exhibits significantly enhanced EQE across the whole visible light spectrum. The $J_{\mathrm{sc}}$ values integrated from the EQE curves are $14.2 \mathrm{~mA} \mathrm{~cm}^{-2}, 9.4 \mathrm{~mA} \mathrm{~cm}^{-2}$ and $8.9 \mathrm{~mA} \mathrm{~cm} \mathrm{~cm}^{-2}$ for $(3 \mathrm{AMPY})(\mathrm{MA})_{3} \mathrm{~Pb}_{4} \mathrm{I}_{13},(4 \mathrm{AMPY})(\mathrm{MA})_{3} \mathrm{~Pb}_{4} \mathrm{I}_{13}$ and $(3 \mathrm{AMP})(\mathrm{MA})_{3} \mathrm{~Pb}_{4} \mathrm{I}_{13}$, respectively, which are in good agreement with the $J_{\text {sc }}$ values obtained from the $J-V$ curves. The onset of the EQE curves matches well with the slope in the absorption spectra (Figure $7 \mathrm{~b}$ ). The improved photovoltaic performance especially the enhanced $J_{\mathrm{sc}}$ can be attributed to the high crystallinity and good vertically preferred orientation, as well as the long PL lifetime of the film as discussed above. Also noted above, the 3AMPY cation has a larger dielectric constant for the aromatic cation than the aliphatic analogue 3AMP, thus smaller dielectric confinement effect and exciton binding energy, which is beneficial for the charge separation in the device. All these reasons are expected to contribute to the sizably higher $J_{\text {sc }}$ and PCE of the (3AMPY)(MA) ${ }_{3} \mathrm{~Pb}_{4} \mathrm{I}_{13}$ devices. 


\section{Conclusions}

Understanding how the cations influence the structure and even properties of the $2 \mathrm{D}$ and 3D perovskites is an essential step for the rational design of better materials for optoelectronic device applications. Here we have extended the nascent class of 2D Dion-Jacobson halide perovskites to a set of compounds with the aromatic ring containing pyridinium based dication 4AMPY for $n=1-4$. The nature of the organic spacer cation such as size, shape and charge has a significant influence of the optical properties of the inorganic halide $\left[\mathrm{Pb}_{n} \mathrm{I}_{3 \mathrm{n}+1}\right]$ layers. In order to understand this influence, it is necessary to obtain precise structural information from single crystal X-ray diffraction data. This affords us the opportunity to compare the structures and properties of the title materials with those of the aliphatic piperidinium containing versions. The organic cations have a strong impact on the structure of the perovskites, influencing not only the tilts of octahedra but also the stacking of the inorganic layers. 2D Dion-Jacobson halide perovskites can be templated by the aromatic 4AMPY cation. With the 3AMPY cation, the octahedra are slightly offset, and the less tilted structures of octahedra result in smaller bandgaps in the 3AMPY series than in the 4AMPY series. Compared to the previously reported aliphatic series, the aromatic cations exhibit larger dielectric constants and thus the corresponding compounds show smaller exciton binding energy, which may benefit charge transport. Solar cells using (3AMPY)(MA) ${ }_{3} \mathrm{~Pb}_{4} \mathrm{I}_{13}$ as the absorber show outstanding photovoltaic performance, with a champion PCE of $9.2 \%$ and promise much higher efficiencies with better device architectures.

\section{Associate content \\ Supporting information}

More experimental details for X-ray diffraction, absorption spectroscopy, crystallographic details, TRPL data and device data.

X-ray crystallographic data of $(3 A M P Y)(M A)_{n-1} P_{n} I_{3 n+1}(n=1-4)$.

X-ray crystallographic data of (4AMPY)(MA) $)_{n-1} \mathrm{~Pb}_{n} \mathrm{I}_{3 \mathrm{n}+1}(\mathrm{n}=1-4)$.

\section{Author information}

\section{Corresponding Author}


*m-kanatzidis@northwestern.edu

\section{Notes}

The authors declare no competing financial interest.

\section{Acknowledgements}

This work was supported by the Office of Naval Research, under Grant N00014-17-1-2231 (synthesis, structural characterization of materials M.G.K.). X.L. acknowledges help by Dr. Jianchun Wang for calculation of the charge distribution in the 3AMPY and 4AMPY cations. M. K. acknowledges support from Region Bretagne through Boost'ERC LaHPerOS project. J.E acknowledges the financial support from the Institut Universitaire de France. This research used the Center for Nanoscale Materials and the Advanced Photon Source at Argonne National Laboratory, both supported by the U.S. Department of Energy, Office of Science, Office of Basic Energy Sciences, under contract no. DE-AC02-06CH11357. This work made use of the SPID (confocal microscopy) and EPIC (scanning electron microscopy) facilities of Northwestern University's NUANCE Center, which has received support from the Soft and Hybrid Nanotechnology Experimental Resource (NSF ECCS1542205), the Materials Research Science and Engineering Centers (NSF DMR-1720139), the International Institute for Nanotechnology (IIN), the Keck Foundation, and the State of Illinois through the IIN. 


\section{References}

1. Arora, N.; Dar, M. I.; Hinderhofer, A.; Pellet, N.; Schreiber, F.; Zakeeruddin, S. M.; Grätzel, M., Perovskite solar cells with CuSCN hole extraction layers yield stabilized efficiencies greater than 20\%. Science 2017, 358 (6364), 768-771.

2. Tsai, H.; Asadpour, R.; Blancon, J.-C.; Stoumpos, C. C.; Durand, O.; Strzalka, J. W.; Chen, B.; Verduzco, R.; Ajayan, P. M.; Tretiak, S.; Even, J.; Alam, M. A.; Kanatzidis, M. G.; Nie, W.; Mohite, A. D., Light-induced lattice expansion leads to high-efficiency perovskite solar cells. Science 2018, 360 (6384), 67-70.

3. Yang, W. S.; Park, B.-W.; Jung, E. H.; Jeon, N. J.; Kim, Y. C.; Lee, D. U.; Shin, S. S.; Seo, J.; Kim, E. K.; Noh, J. H.; Seok, S. I., Iodide management in formamidinium-lead-halide-based perovskite layers for efficient solar cells. Science 2017, 356 (6345), 1376-1379.

4. Cao, Y.; Wang, N.; Tian, H.; Guo, J.; Wei, Y.; Chen, H.; Miao, Y.; Zou, W.; Pan, K.; He, Y.; Cao, H.; Ke, Y.; Xu, M.; Wang, Y.; Yang, M.; Du, K.; Fu, Z.; Kong, D.; Dai, D.; Jin, Y.; Li, G.; Li, H.; Peng, Q.; Wang, J.; Huang, W., Perovskite light-emitting diodes based on spontaneously formed submicrometre-scale structures. Nature 2018, 562 (7726), 249-253.

5. Lin, K.; Xing, J.; Quan, L. N.; de Arquer, F. P. G.; Gong, X.; Lu, J.; Xie, L.; Zhao, W.; Zhang, D.; Yan, C.; Li, W.; Liu, X.; Lu, Y.; Kirman, J.; Sargent, E. H.; Xiong, Q.; Wei, Z., Perovskite light-emitting diodes with external quantum efficiency exceeding 20 percent. Nature 2018, 562 (7726), 245-248.

6. Tsai, H.; Nie, W.; Blancon, J.-C.; Stoumpos, C. C.; Soe, C. M. M.; Yoo, J.; Crochet, J.; Tretiak, S.; Even, J.; Sadhanala, A.; Azzellino, G.; Brenes, R.; Ajayan, P. M.; Bulović, V.; Stranks, S. D.; Friend, R. H.; Kanatzidis, M. G.; Mohite, A. D., Stable Light-Emitting Diodes Using PhasePure Ruddlesden-Popper Layered Perovskites. Adv. Mater. 2018, 30 (6), 1704217.

7. He, Y.; Matei, L.; Jung, H. J.; McCall, K. M.; Chen, M.; Stoumpos, C. C.; Liu, Z.; Peters, J. A.; Chung, D. Y.; Wessels, B. W.; Wasielewski, M. R.; Dravid, V. P.; Burger, A.; Kanatzidis, M. G., High spectral resolution of gamma-rays at room temperature by perovskite $\mathrm{CsPbBr}_{3}$ single crystals. Nat. Commun. 2018, 9 (1), 1609.

8. He, Y.; Ke, W.; Alexander, G. C. B.; McCall, K. M.; Chica, D. G.; Liu, Z.; Hadar, I.; Stoumpos, C. C.; Wessels, B. W.; Kanatzidis, M. G., Resolving the Energy of $\gamma$-Ray Photons with $\mathrm{MAPbI}_{3}$ Single Crystals. ACS Photonics 2018, 5 (10), 4132-4138.

9. Eaton, S. W.; Lai, M.; Gibson, N. A.; Wong, A. B.; Dou, L.; Ma, J.; Wang, L.-W.; Leone, S. R.; Yang, P., Lasing in robust cesium lead halide perovskite nanowires. Proc. Natl. Acad. Sci. 2016, 113 (8), 1993-1998.

10. Zhu, H.; Fu, Y.; Meng, F.; Wu, X.; Gong, Z.; Ding, Q.; Gustafsson, M. V.; Trinh, M. T.; Jin, S.; Zhu, X. Y., Lead halide perovskite nanowire lasers with low lasing thresholds and high quality factors. Nat. Mater. 2015, 14, 636.

11. Stoumpos, C. C.; Kanatzidis, M. G., The Renaissance of Halide Perovskites and Their Evolution as Emerging Semiconductors. Acc. Chem. Res. 2015, 48 (10), 2791-2802.

12. Stoumpos, C. C.; Kanatzidis, M. G., Halide Perovskites: Poor Man's High-Performance Semiconductors. Adv. Mater. 2016, 28 (28), 5778-5793.

13. Ke, W.; Stoumpos, C. C.; Zhu, M.; Mao, L.; Spanopoulos, I.; Liu, J.; Kontsevoi, O. Y.; Chen, M.; Sarma, D.; Zhang, Y.; Wasielewski, M. R.; Kanatzidis, M. G., Enhanced photovoltaic performance and stability with a new type of hollow 3D perovskite $\{$ en $\} \mathrm{FASnI}_{3}$. Sci. Adv. 2017, 3 (8), e1701293. 
14. Spanopoulos, I.; Ke, W.; Stoumpos, C. C.; Schueller, E. C.; Kontsevoi, O. Y.; Seshadri, R.; Kanatzidis, M. G., Unraveling the Chemical Nature of the 3D "Hollow" Hybrid Halide Perovskites. J. Am. Chem. Soc. 2018, 140 (17), 5728-5742.

15. Leblanc, A.; Mercier, N.; Allain, M.; Dittmer, J.; Fernandez, V.; Pauporté, T., Lead- and Iodide-Deficient (CH3NH3)PbI3 (d-MAPI): The Bridge between 2D and 3D Hybrid Perovskites. Angewandte Chemie International Edition 2017, 56 (50), 16067-16072.

16. Leblanc, A.; Mercier, N.; Allain, M.; Dittmer, J.; Pauporté, T.; Fernandez, V.; Boucher, F.; Kepenekian, M.; Katan, C., Enhanced Stability and Band Gap Tuning of $\alpha-\left[\mathrm{HC}\left(\mathrm{NH}_{2}\right)_{2}\right] \mathrm{PbI}_{3}$ Hybrid Perovskite by Large Cation Integration. ACS Applied Materials \& Interfaces 2019, 11 (23), 20743-20751.

17. Saparov, B.; Mitzi, D. B., Organic-Inorganic Perovskites: Structural Versatility for Functional Materials Design. Chem. Rev. 2016, 116 (7), 4558-4596.

18. Mao, L.; Stoumpos, C. C.; Kanatzidis, M. G., Two-Dimensional Hybrid Halide Perovskites: Principles and Promises. J. Am. Chem. Soc. 2019, 141 (3), 1171-1190.

19. Katan, C.; Mercier, N.; Even, J., Quantum and Dielectric Confinement Effects in LowerDimensional Hybrid Perovskite Semiconductors. Chem. Rev. 2019, 119 (5), 3140-3192.

20. Smith, M. D.; Connor, B. A.; Karunadasa, H. I., Tuning the Luminescence of Layered Halide Perovskites. Chem. Rev. 2019, 119 (5), 3104-3139.

21. Cao, D. H.; Stoumpos, C. C.; Farha, O. K.; Hupp, J. T.; Kanatzidis, M. G., 2D Homologous Perovskites as Light-Absorbing Materials for Solar Cell Applications. J. Am. Chem. Soc. 2015, 137 (24), 7843-7850.

22. Tsai, H.; Nie, W.; Blancon, J.-C.; Stoumpos, C. C.; Asadpour, R.; Harutyunyan, B.; Neukirch, A. J.; Verduzco, R.; Crochet, J. J.; Tretiak, S.; Pedesseau, L.; Even, J.; Alam, M. A.; Gupta, G.; Lou, J.; Ajayan, P. M.; Bedzyk, M. J.; Kanatzidis, M. G.; Mohite, A. D., Highefficiency two-dimensional Ruddlesden-Popper perovskite solar cells. Nature 2016, 536 (7616), 312-316.

23. Ke, W.; Mao, L.; Stoumpos, C. C.; Hoffman, J.; Spanopoulos, I.; Mohite, A. D.; Kanatzidis, M. G., Compositional and Solvent Engineering in Dion-Jacobson 2D Perovskites Boosts Solar Cell Efficiency and Stability. Adv. Energy Mater. 2019, 9, 1803384.

24. Yuan, M.; Quan, L. N.; Comin, R.; Walters, G.; Sabatini, R.; Voznyy, O.; Hoogland, S.; Zhao, Y.; Beauregard, E. M.; Kanjanaboos, P.; Lu, Z.; Kim, D. H.; Sargent, E. H., Perovskite energy funnels for efficient light-emitting diodes. Nat. Nanotechnol. 2016, 11 (10), 872-877.

25. Dohner, E. R.; Hoke, E. T.; Karunadasa, H. I., Self-Assembly of Broadband White-Light Emitters. J. Am. Chem. Soc. 2014, 136 (5), 1718-1721.

26. Dohner, E. R.; Jaffe, A.; Bradshaw, L. R.; Karunadasa, H. I., Intrinsic White-Light Emission from Layered Hybrid Perovskites. J. Am. Chem. Soc. 2014, 136 (38), 13154-13157.

27. Mao, L.; Wu, Y.; Stoumpos, C. C.; Wasielewski, M. R.; Kanatzidis, M. G., White-Light Emission and Structural Distortion in New Corrugated Two-Dimensional Lead Bromide Perovskites. J. Am. Chem. Soc. 2017, 139 (14), 5210-5215.

28. Li, X.; Guo, P.; Kepenekian, M.; Hadar, I.; Katan, C.; Even, J.; Stoumpos, C. C.; Schaller, R. D.; Kanatzidis, M. G., Small Cyclic Diammonium Cation Templated (110)-Oriented 2D Halide (X = I, Br, Cl) Perovskites with White-Light Emission. Chem. Mater. 2019, 31 (9), 3582-3590.

29. Stoumpos, C. C.; Cao, D. H.; Clark, D. J.; Young, J.; Rondinelli, J. M.; Jang, J. I.; Hupp, J. T.; Kanatzidis, M. G., Ruddlesden-Popper Hybrid Lead Iodide Perovskite 2D Homologous Semiconductors. Chem. Mater. 2016, 28 (8), 2852-2867. 
30. Mao, L.; Ke, W.; Pedesseau, L.; Wu, Y.; Katan, C.; Even, J.; Wasielewski, M. R.; Stoumpos, C. C.; Kanatzidis, M. G., Hybrid Dion-Jacobson 2D Lead Iodide Perovskites. J. Am. Chem. Soc. 2018, 140 (10), 3775-3783.

31. Soe, C. M. M.; Stoumpos, C. C.; Kepenekian, M.; Traoré, B.; Tsai, H.; Nie, W.; Wang, B.; Katan, C.; Seshadri, R.; Mohite, A. D.; Even, J.; Marks, T. J.; Kanatzidis, M. G., New Type of 2D

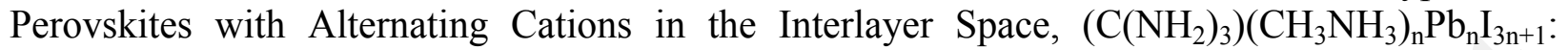
Structure, Properties, and Photovoltaic Performance. J. Am. Chem. Soc. 2017, 139 (45), 1629716309.

32. Nazarenko, O.; Kotyrba, M. R.; Wörle, M.; Cuervo-Reyes, E.; Yakunin, S.; Kovalenko, M. V., Luminescent and Photoconductive Layered Lead Halide Perovskite Compounds Comprising Mixtures of Cesium and Guanidinium Cations. Inorg. Chem. 2017, 56 (19), 1155211564.

33. Li, X.; Hoffman, J.; Ke, W.; Chen, M.; Tsai, H.; Nie, W.; Mohite, A. D.; Kepenekian, M.; Katan, C.; Even, J.; Wasielewski, M. R.; Stoumpos, C. C.; Kanatzidis, M. G., Two-Dimensional Halide Perovskites Incorporating Straight Chain Symmetric Diammonium Ions, $\left(\mathrm{NH}_{3} \mathrm{C}_{\mathrm{m}} \mathrm{H}_{2 \mathrm{~m}} \mathrm{NH}_{3}\right)\left(\mathrm{CH}_{3} \mathrm{NH}_{3}\right)_{\mathrm{n}-1} \mathrm{~Pb}_{\mathrm{n}} \mathrm{I}_{3 \mathrm{n}+1}(\mathrm{~m}=4-9 ; \mathrm{n}=1-4)$. J. Am. Chem. Soc. 2018, 140 (38), 12226-12238.

34. Rayner, M. K.; Billing, D. G., Poly[1,4-bis(ammoniomethyl)cyclohexane [di-[mu]-iodidodiiodidoplumbate(II)]]. Acta Crystallogr. E 2010, 66 (6), m660.

35. Chen, M.; Ju, M.-G.; Hu, M.; Dai, Z.; Hu, Y.; Rong, Y.; Han, H.; Zeng, X. C.; Zhou, Y.; Padture, N. P., Lead-Free Dion-Jacobson Tin Halide Perovskites for Photovoltaics. ACS Energy Lett. 2019, 4 (1), 276-277.

36. Li, Y.; Milić, J. V.; Ummadisingu, A.; Seo, J.-Y.; Im, J.-H.; Kim, H.-S.; Liu, Y.; Dar, M. I.; Zakeeruddin, S. M.; Wang, P.; Hagfeldt, A.; Grätzel, M., Bifunctional Organic Spacers for Formamidinium-Based Hybrid Dion-Jacobson Two-Dimensional Perovskite Solar Cells. Nano Lett. 2019, 19 (1), 150-157.

37. Dobrzycki, L.; Woźniak, K., Inorganic-organic hybrid salts of diaminobenzenes and related cations. CrystEngComm 2008, 10 (5), 577-589.

38. Lemmerer, A.; Billing, D. G., Lead halide inorganic-organic hybrids incorporating diammonium cations. CrystEngComm 2012, 14 (6), 1954-1966.

39. Petř́iček, V.; Dušek, M.; Palatinus, L., Crystallographic Computing System JANA2006: General features. Z. Kristallogr. - Cryst. Mater. 2014, 229 (5), 345.

40. Spek, A., Structure validation in chemical crystallography. Acta Crystallogr. D 2009, 65 (2), 148-155.

41. Barman, S.; Venkataraman, N. V.; Vasudevan, S.; Seshadri, R., Phase Transitions in the Anchored Organic Bilayers of Long-Chain Alkylammonium Lead Iodides $\left(\mathrm{C}_{\mathrm{n}} \mathrm{H}_{2 \mathrm{n}+1} \mathrm{NH}_{3}\right)_{2} \mathrm{PbI}_{4} ; \mathrm{n}=$ 12, 16, 18. J. Phys. Chem. B 2003, 107 (8), 1875-1883.

42. Janiak, C., A critical account on $\pi-\pi$ stacking in metal complexes with aromatic nitrogencontaining ligands. J. Chem. Soc., Dalton Trans. 2000, (21), 3885-3896.

43. Mitzi, D. B., Organic-Inorganic Perovskites Containing Trivalent Metal Halide Layers: The Templating Influence of the Organic Cation Layer. Inorg. Chem. 2000, 39 (26), 6107-6113.

44. Du, K.-Z.; Tu, Q.; Zhang, X.; Han, Q.; Liu, J.; Zauscher, S.; Mitzi, D. B., Two-Dimensional Lead(II) Halide-Based Hybrid Perovskites Templated by Acene Alkylamines: Crystal Structures, Optical Properties, and Piezoelectricity. Inorg. Chem. 2017, 56 (15), 9291-9302.

45. Jana, M. K.; Janke, S. M.; Dirkes, D. J.; Dovletgeldi, S.; Liu, C.; Qin, X.; Gundogdu, K.; You, W.; Blum, V.; Mitzi, D. B., A Direct-Bandgap 2D Silver-Bismuth Iodide Double Perovskite: 
The Structure-Directing Influence of an Oligothiophene Spacer Cation. J. Am. Chem. Soc. 2019, 141 (19), 7955-7964.

46. Knutson, J. L.; Martin, J. D.; Mitzi, D. B., Tuning the Band Gap in Hybrid Tin Iodide Perovskite Semiconductors Using Structural Templating. Inorg. Chem. 2005, 44 (13), 4699-4705. 47. Pedesseau, L.; Sapori, D.; Traore, B.; Robles, R.; Fang, H.-H.; Loi, M. A.; Tsai, H.; Nie, W.; Blancon, J.-C.; Neukirch, A.; Tretiak, S.; Mohite, A. D.; Katan, C.; Even, J.; Kepenekian, M., Advances and Promises of Layered Halide Hybrid Perovskite Semiconductors. ACS Nano 2016, 10 (11), 9776-9786.

48. Peng, W.; Yin, J.; Ho, K.-T.; Ouellette, O.; De Bastiani, M.; Murali, B.; El Tall, O.; Shen, C.; Miao, X.; Pan, J.; Alarousu, E.; He, J.-H.; Ooi, B. S.; Mohammed, O. F.; Sargent, E.; Bakr, O. M., Ultralow Self-Doping in Two-dimensional Hybrid Perovskite Single Crystals. Nano Lett. 2017, 17 (8), 4759-4767.

49. Saouma, F. O.; Stoumpos, C. C.; Wong, J.; Kanatzidis, M. G.; Jang, J. I., Selective enhancement of optical nonlinearity in two-dimensional organic-inorganic lead iodide perovskites. Nat. Commun. 2017, 8 (1), 742.

50. Muljarov, E. A.; Tikhodeev, S. G.; Gippius, N. A.; Ishihara, T., Excitons in self-organized semiconductor/insulator superlattices: PbI-based perovskite compounds. Phys. Rev. B 1995, 51 (20), 14370-14378.

51. Hong, X.; Ishihara, T.; Nurmikko, A. V., Dielectric confinement effect on excitons in $\mathrm{PbI}_{4}$ based layered semiconductors. Phys. Rev. B 1992, 45 (12), 6961-6964.

52. Ishihara, T.; Takahashi, J.; Goto, T., Exciton state in two-dimensional perovskite semiconductor $\left(\mathrm{C}_{10} \mathrm{H}_{21} \mathrm{NH}_{3}\right)_{2} \mathrm{PbI}_{4}$. Solid State Commun. 1989, 69 (9), 933-936.

53. Ishihara, T.; Hong, X.; Ding, J.; Nurmikko, A. V., Dielectric confinement effect for exciton and biexciton states in $\mathrm{PbI}_{4}$-based two-dimensional semiconductor structures. Surf. Sci. 1992, 267 (1), 323-326.

54. Kataoka, T.; Kondo, T.; Ito, R.; Sasaki, S.; Uchida, K.; Miura, N., Magneto-optical study on excitonic spectra in $\left(\mathrm{C}_{6} \mathrm{H}_{13} \mathrm{NH}_{3}\right)_{2} \mathrm{PbI}_{4}$. Phys. Rev. B 1993, 47 (4), 2010-2018.

55. Blancon, J. C.; Stier, A. V.; Tsai, H.; Nie, W.; Stoumpos, C. C.; Traoré, B.; Pedesseau, L.; Kepenekian, M.; Katsutani, F.; Noe, G. T.; Kono, J.; Tretiak, S.; Crooker, S. A.; Katan, C.; Kanatzidis, M. G.; Crochet, J. J.; Even, J.; Mohite, A. D., Scaling law for excitons in 2D perovskite quantum wells. Nat. Commun. 2018, 9 (1), 2254. 
Table 1. Crystal and Refinement Data for (xAMPY)(MA) $)_{n-1} \mathrm{~Pb}_{\mathrm{n}} \mathrm{I}_{3 \mathrm{n}+1}(\mathrm{x}=3$ or $4, \mathrm{n}=1-4)$.

\begin{tabular}{|c|c|c|c|c|}
\hline Compound & $(3 \mathrm{AMPY}) \mathrm{PbI}_{4}$ & $(3 \mathrm{AMPY})(\mathrm{MA}) \mathrm{Pb}_{2} \mathrm{I}_{7}$ & $(3 \mathrm{AMPY})(\mathrm{MA})_{2} \mathrm{~Pb}_{3} \mathrm{I}_{10}$ & $(3 \mathrm{AMPY})(\mathrm{MA})_{3} \mathrm{~Pb}_{4} \mathrm{I}_{13}$ \\
\hline Crystal system & monoclinic & monoclinic & monoclinic & monoclinic \\
\hline Space group & $P n$ & $P c$ & $C c$ & $P c$ \\
\hline Unit cell dimensions & $\begin{array}{l}\mathrm{a}=9.1223(13) \AA \\
\mathrm{b}=8.7787(12) \AA \\
\mathrm{c}=19.830(4) \AA \\
\beta=90.103(13)^{\circ}\end{array}$ & $\begin{array}{l}\mathrm{a}=16.2400(7) \AA \\
\mathrm{b}=9.0384(5) \AA \\
\mathrm{c}=8.8082(16) \AA \\
\beta=97.619(7)^{\circ}\end{array}$ & $\begin{array}{l}\mathrm{a}=45.091(5) \AA \\
\mathrm{b}=9.0494(15) \AA \\
\mathrm{c}=8.8654(10) \AA \\
\beta=95.920(9)^{\circ}\end{array}$ & $\begin{array}{l}\mathrm{a}=28.8181(10) \AA \\
\mathrm{b}=9.0332(14) \AA \\
\mathrm{c}=8.882(3) \AA \\
\beta=94.138(9)^{\circ}\end{array}$ \\
\hline Volume & $1588.0(4) \AA^{3}$ & $1281.5(3) \AA^{3}$ & $3598.2(8) \AA^{3}$ & $2306.2(9) \AA^{3}$ \\
\hline $\mathrm{Z}$ & 4 & 2 & 4 & 2 \\
\hline Density (calculated) & $3.4506 \mathrm{~g} / \mathrm{cm}^{3}$ & $3.7447 \mathrm{~g} / \mathrm{cm}^{3}$ & $3.8117 \mathrm{~g} / \mathrm{cm}^{3}$ & $3.8664 \mathrm{~g} / \mathrm{cm}^{3}$ \\
\hline $\begin{array}{l}\text { Independent } \\
\text { reflections }\end{array}$ & $5481\left[\mathrm{R}_{\mathrm{int}}=0.1152\right]$ & $4246\left[\mathrm{R}_{\mathrm{int}}=0.0841\right]$ & $6220\left[\mathrm{R}_{\mathrm{int}}=0.1593\right]$ & $7828\left[\mathrm{R}_{\mathrm{int}}=0.1488\right]$ \\
\hline Completeness to $25^{\circ}$ & $99 \%$ & $99 \%$ & $99 \%$ & $99 \%$ \\
\hline $\begin{array}{l}\text { Data / restraints / } \\
\text { parameters }\end{array}$ & $5481 / 34$ / 142 & 4246 / 25 / 116 & $6220 / 26 / 157$ & 7828 / 27 / 200 \\
\hline Goodness-of-fit & 6.20 & 3.17 & 5.92 & 4.80 \\
\hline $\begin{array}{l}\text { Final } R \text { indices } \\
{[\mathrm{I}>2 \sigma(\mathrm{I})]}\end{array}$ & $\begin{array}{l}\mathrm{R}_{\mathrm{obs}}=0.1219 \\
\mathrm{wR}_{\mathrm{obs}}=0.1322\end{array}$ & $\begin{array}{l}\mathrm{R}_{\mathrm{obs}}=0.0944 \\
\mathrm{wR}_{\mathrm{obs}}=0.1640\end{array}$ & $\begin{array}{l}\mathrm{R}_{\mathrm{obs}}=0.1285 \\
\mathrm{wR}_{\mathrm{obs}}=0.1663\end{array}$ & $\begin{array}{l}\mathrm{R}_{\mathrm{obs}}=0.1234 \\
\mathrm{wR}_{\mathrm{obs}}=0.1619\end{array}$ \\
\hline $\mathrm{R}$ indices [all data] & $\begin{array}{l}\mathrm{R}_{\mathrm{all}}=0.1612 \\
\mathrm{wR}_{\mathrm{all}}=0.1348\end{array}$ & $\begin{array}{l}\mathrm{R}_{\mathrm{all}}=0.1281 \\
\mathrm{wR}_{\mathrm{all}}=0.1676\end{array}$ & $\begin{array}{l}\mathrm{R}_{\mathrm{all}}=0.1867 \\
\mathrm{wR}_{\mathrm{all}}=0.1674\end{array}$ & $\begin{array}{l}\mathrm{R}_{\mathrm{all}}=0.2114 \\
\mathrm{wR}_{\mathrm{all}}=0.1632\end{array}$ \\
\hline $\begin{array}{l}\text { Largest diff. peak } \\
\text { and hole }\end{array}$ & 4.07 and $-5.56 \mathrm{e} \cdot \AA^{-3}$ & 7.83 and $-2.39 \mathrm{e} \cdot \AA^{-3}$ & 8.45 and $-6.03 \mathrm{e} \cdot \AA^{-3}$ & 4.22 and $-5.51 \mathrm{e} \cdot \AA^{-3}$ \\
\hline Compound & $(4 \mathrm{AMPY}) \mathrm{PbI}_{4}$ & $(4 \mathrm{AMPY})(\mathrm{MA}) \mathrm{Pb}_{2} \mathrm{I}_{7}$ & $(4 \mathrm{AMPY})(\mathrm{MA})_{2} \mathrm{~Pb}_{3} \mathrm{I}_{10}$ & $(4 \mathrm{AMPY})(\mathrm{MA})_{3} \mathrm{~Pb}_{4} \mathrm{I}_{13}$ \\
\hline Crystal system & monoclinic & monoclinic & monoclinic & monoclinic \\
\hline Space group & $P n$ & $C c$ & $P c$ & Ic \\
\hline Unit cell dimensions & $\begin{array}{l}\mathrm{a}=12.3348(12) \AA \\
\mathrm{b}=10.5038(7) \AA \\
\mathrm{c}=12.3423(12) \AA \\
\beta=90.002(8)^{\circ} \\
1599.1(2) \AA^{3}\end{array}$ & $\begin{array}{l}\mathrm{a}=34.678(4) \AA \\
\mathrm{b}=8.7791(10) \AA \\
\mathrm{c}=8.7644(9) \AA \\
\beta=104.536(8)^{\circ} \\
2582.8(5) \AA^{3}\end{array}$ & $\begin{array}{l}\mathrm{a}=23.175(3) \AA \\
\mathrm{b}=8.8255(7) \AA \\
\mathrm{c}=8.8238(9) \AA \\
\beta=90.0045^{\circ} \\
1804.7(3) \AA^{3}\end{array}$ & $\begin{array}{l}\mathrm{a}=59.166(9) \AA \\
\mathrm{b}=8.8404(10) \AA \\
\mathrm{c}=8.8405(13) \AA \\
\beta=90.000(12)^{\circ} \\
4624.0(11) \AA^{3}\end{array}$ \\
\hline $\mathrm{Z}$ & 4 & 4 & 2 & 4 \\
\hline Density (calculated) & $3.4267 \mathrm{~g} / \mathrm{cm}^{3}$ & $3.7159 \mathrm{~g} / \mathrm{cm}^{3}$ & $3.7999 \mathrm{~g} / \mathrm{cm}^{3}$ & $3.8596 \mathrm{~g} / \mathrm{cm}^{3}$ \\
\hline $\begin{array}{l}\text { Independent } \\
\text { reflections }\end{array}$ & $5458\left[\mathrm{R}_{\mathrm{int}}=0.0873\right]$ & $4457\left[\mathrm{R}_{\mathrm{int}}=0.0453\right]$ & $6245\left[\mathrm{R}_{\mathrm{int}}=0.0837\right]$ & $7811\left[\mathrm{R}_{\mathrm{int}}=0.0591\right]$ \\
\hline Completeness to $25^{\circ}$ & $99 \%$ & $98 \%$ & $99 \%$ & $99 \%$ \\
\hline $\begin{array}{l}\text { Data / restraints / } \\
\text { parameters }\end{array}$ & 5458 / 36 / 142 & 4457 / 18 / 116 & 6245 / 26 / 158 & $7811 / 20$ / 201 \\
\hline Goodness-of-fit & 3.85 & 1.75 & 3.46 & 2.73 \\
\hline $\begin{array}{l}\text { Final } R \text { indices } \\
{[\mathrm{I}>2 \sigma(\mathrm{I})]}\end{array}$ & $\begin{array}{l}\mathrm{R}_{\mathrm{obs}}=0.0616 \\
\mathrm{wR}_{\mathrm{obs}}=0.0691\end{array}$ & $\begin{array}{l}\mathrm{R}_{\mathrm{obs}}=0.0337 \\
\mathrm{wR}_{\mathrm{obs}}=0.0693\end{array}$ & $\begin{array}{l}\mathrm{R}_{\mathrm{obs}}=0.0522 \\
\mathrm{wR}_{\mathrm{obs}}=0.0757\end{array}$ & $\begin{array}{l}\mathrm{R}_{\mathrm{obs}}=0.0478 \\
\mathrm{wR}_{\mathrm{obs}}=0.1053\end{array}$ \\
\hline $\mathrm{R}$ indices [all data] & $\begin{array}{l}\mathrm{R}_{\mathrm{all}}=0.0705 \\
\mathrm{wR}_{\mathrm{all}}=0.0694\end{array}$ & $\begin{array}{l}\mathrm{R}_{\mathrm{all}}=0.0591 \\
\mathrm{wR}_{\mathrm{all}}=0.0734\end{array}$ & $\begin{array}{l}\mathrm{R}_{\mathrm{all}}=0.0764 \\
\mathrm{wR}_{\mathrm{all}}=0.0765\end{array}$ & $\begin{array}{l}\mathrm{R}_{\mathrm{all}}=0.0872 \\
\mathrm{wR}_{\mathrm{all}}=0.1424\end{array}$ \\
\hline $\begin{array}{l}\text { Largest diff. peak } \\
\text { and hole }\end{array}$ & 1.36 and $-1.35 \mathrm{e} \cdot \AA^{-3}$ & 1.09 and $-0.83 \mathrm{e} \cdot \AA^{-3}$ & 1.61 and $-1.72 \mathrm{e} \cdot \AA^{-3}$ & 2.55 and $-3.01 \mathrm{e} \cdot \AA^{-3}$ \\
\hline
\end{tabular}


Table 2. Optical Properties and Colors for (xAMPY)(MA) $)_{n-1} \mathrm{~Pb}_{\mathrm{n}} \mathrm{I}_{3 \mathrm{n}+1}(\mathrm{x}=3$ or $4, \mathrm{n}=1-4)$.

\begin{tabular}{ccccccc}
\hline & \multicolumn{3}{c}{ 3AMPY } & \multicolumn{3}{c}{ 4AMPY } \\
\hline & Bandgap $(\mathrm{eV})$ & PL $(\mathrm{eV})$ & Color & Bandgap $(\mathrm{eV})$ & PL $(\mathrm{eV})$ & Color \\
\hline $\mathrm{n}=1$ & 2.34 & 2.23 & red & - & - & orange \\
$\mathrm{n}=2$ & 2.08 & 2.04 & dark red & 2.15 & 2.14 & red \\
$\mathrm{n}=3$ & 1.96 & 1.93 & black & 2.00 & 1.97 & dark red \\
$\mathrm{n}=4$ & 1.87 & 1.85 & black & 1.89 & 1.89 & black \\
\hline
\end{tabular}

Table 3. Comparison of $\mathrm{Pb}-\mathrm{I}-\mathrm{Pb}$ Angles and d-spacing for (xAMPY)(MA) $)_{n-1} \mathrm{~Pb}_{\mathrm{n}} \mathrm{I}_{3 \mathrm{n}+1}(\mathrm{x}=3$ or 4), $(\mathrm{xAMP})(\mathrm{MA})_{\mathrm{n}-1} \mathrm{~Pb}_{\mathrm{n}} \mathrm{I}_{3 \mathrm{n}+1}(\mathrm{x}=3 \text { or } 4)^{30}$, and $(\mathrm{BA})_{2}(\mathrm{MA})_{\mathrm{n}-1} \mathrm{~Pb}_{\mathrm{n}} \mathrm{I}_{3 \mathrm{n}+1}(\mathrm{BA}=\text { butylammonium })^{29}$.

\begin{tabular}{|c|c|c|c|c|c|}
\hline & Layer-number & Axial angle $\left(^{\circ}\right)$ & Equatorial angle $\left({ }^{\circ}\right)$ & Average angle $\left(^{\circ}\right)$ & d-spacing $(\AA)$ \\
\hline & $\mathrm{n}=2$ & 164.4 & 168.9 & 168.0 & 3.55 \\
\hline \multirow[t]{3}{*}{ 3AMPY } & $\mathrm{n}=3$ & 164.8 & 168.0 & 167.2 & 3.59 \\
\hline & $\mathrm{n}=4$ & 165.5 & 168.8 & 167.9 & 3.53 \\
\hline & $\mathrm{n}=2$ & 179.8 & 153.9 & 159.1 & 4.01 \\
\hline \multirow[t]{3}{*}{ 4AMPY } & $\mathrm{n}=3$ & 178.8 & 155.9 & 161.6 & 3.97 \\
\hline & $\mathrm{n}=4$ & 179.2 & 157.3 & 163.2 & 3.99 \\
\hline & $\mathrm{n}=2$ & 180.0 & 163.1 & 166.5 & 4.06 \\
\hline \multirow[t]{3}{*}{ 3AMP } & $\mathrm{n}=3$ & 180.0 & 163.5 & 167.6 & 4.02 \\
\hline & $\mathrm{n}=4$ & 176.5 & 162.2 & 166.1 & 4.00 \\
\hline & $\mathrm{n}=2$ & 179.8 & 156.5 & 161.1 & 4.12 \\
\hline \multirow[t]{3}{*}{ 4AMP } & $\mathrm{n}=3$ & 179.6 & 157.4 & 162.9 & 4.11 \\
\hline & $\mathrm{n}=4$ & 178.6 & 159.7 & 164.9 & 4.10 \\
\hline & $\mathrm{n}=2$ & 165.6 & 167.5 & 167.1 & 7.13 \\
\hline \multirow[t]{2}{*}{ BA } & $n=3$ & 169.5 & 169.4 & 169.4 & 7.10 \\
\hline & $\mathrm{n}=4$ & 166.6 & 168.9 & 169.3 & 7.09 \\
\hline
\end{tabular}



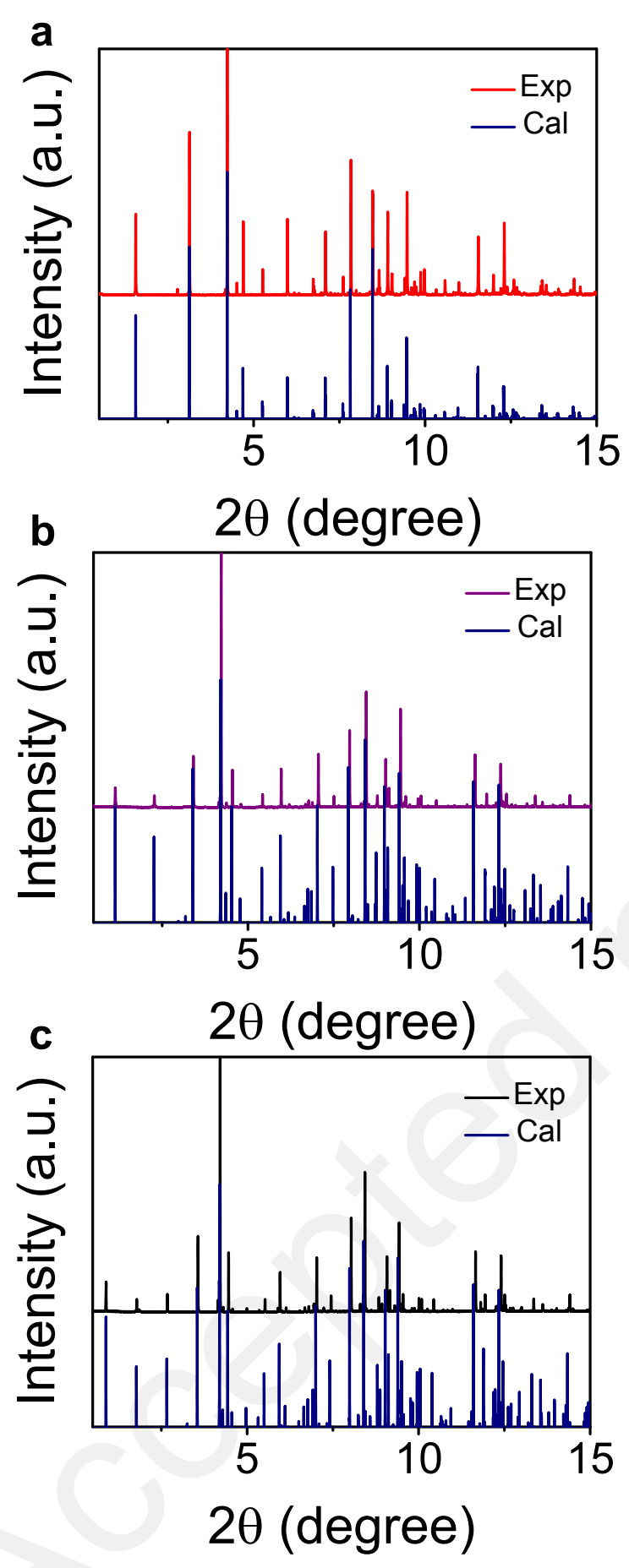

Figure 1. Powder X-ray diffraction (PXRD) patterns for (4AMPY)(MA) $)_{n-1} \mathrm{~Pb}_{n} \mathrm{I}_{3 n+1}(\mathrm{n}=2-4)$ from synchrotron radiation (11-BM, APS, $\lambda=0.4578 \AA$ ). (a) $n=2$. (b) $n=3$. (c) $n=4$. 


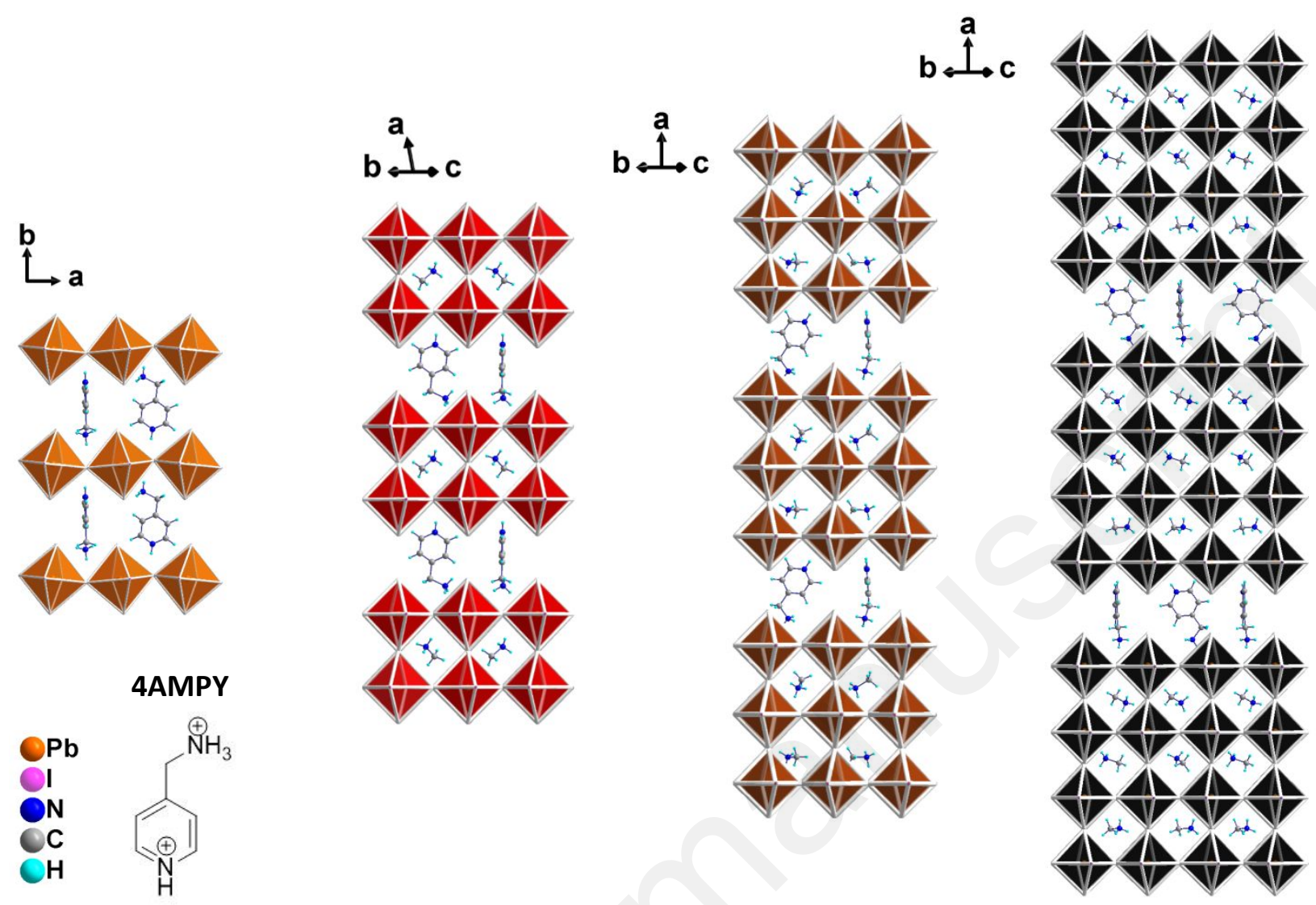

Figure 2. Crystal structures for (4AMPY)(MA) $)_{n-1} \mathrm{~Pb}_{n} \mathrm{I}_{3 n+1}(\mathrm{n}=1-4)$. 


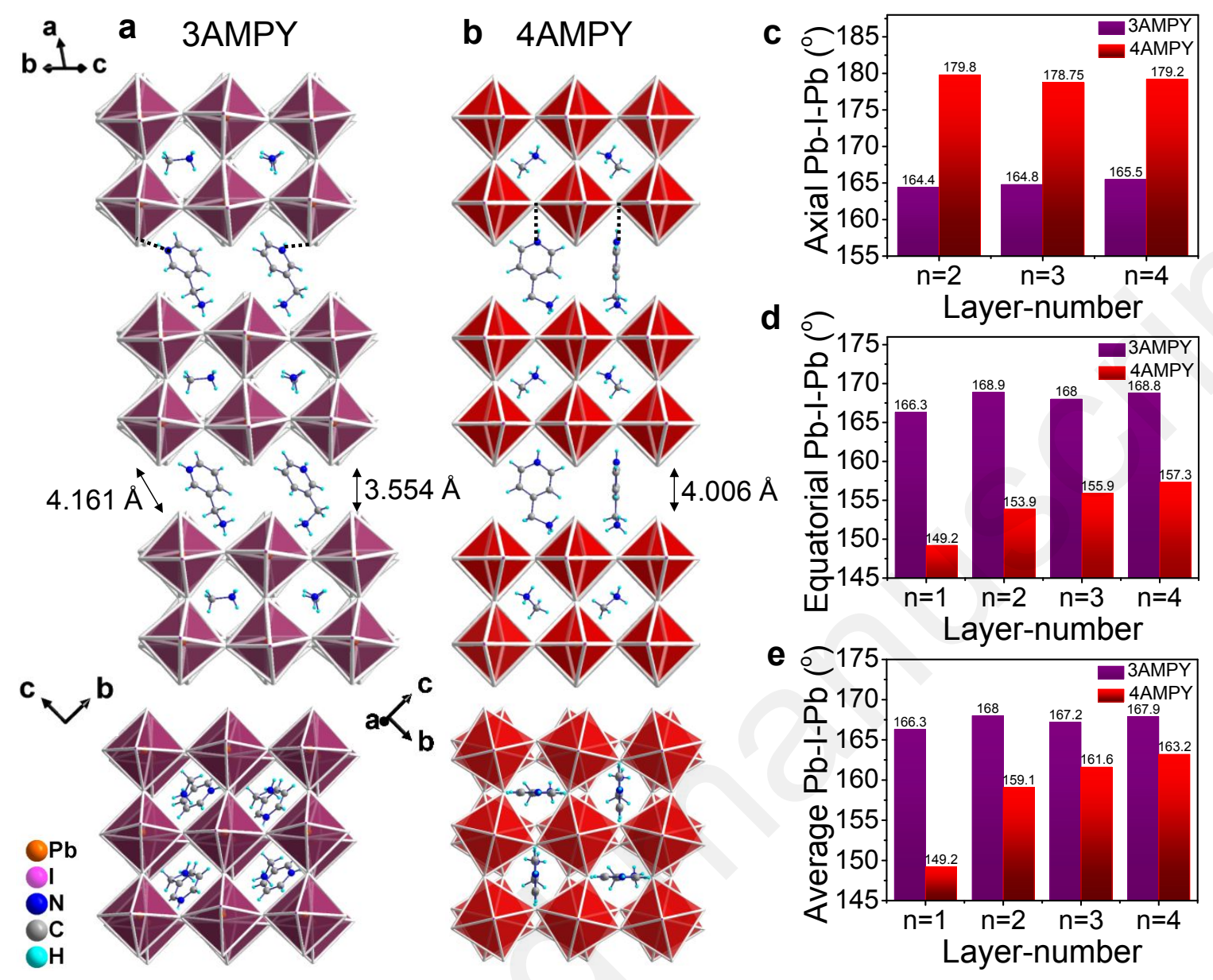

Figure 3. Side and top view of (a) (3AMPY)(MA) $\mathrm{Pb}_{2} \mathrm{I}_{7}$ and (b) (4AMPY)(MA)Pb $\mathrm{I}_{7}$. (Note that the spacer cation in (3AMPY)(MA)Pb $\mathrm{I}_{7}$ is disordered, and we modeled it with restraints of bond lengths and bond angles. Structure shown here is with frozen disorder.) (c) Axial, (d) equatorial and (e) average $\mathrm{Pb}-\mathrm{I}-\mathrm{Pb}$ angles for (xAMPY)(MA) $)_{n-1} \mathrm{~Pb}_{n} \mathrm{I}_{3 \mathrm{n}+1}(\mathrm{x}=3$ or $4, \mathrm{n}=1-4)$. 
b
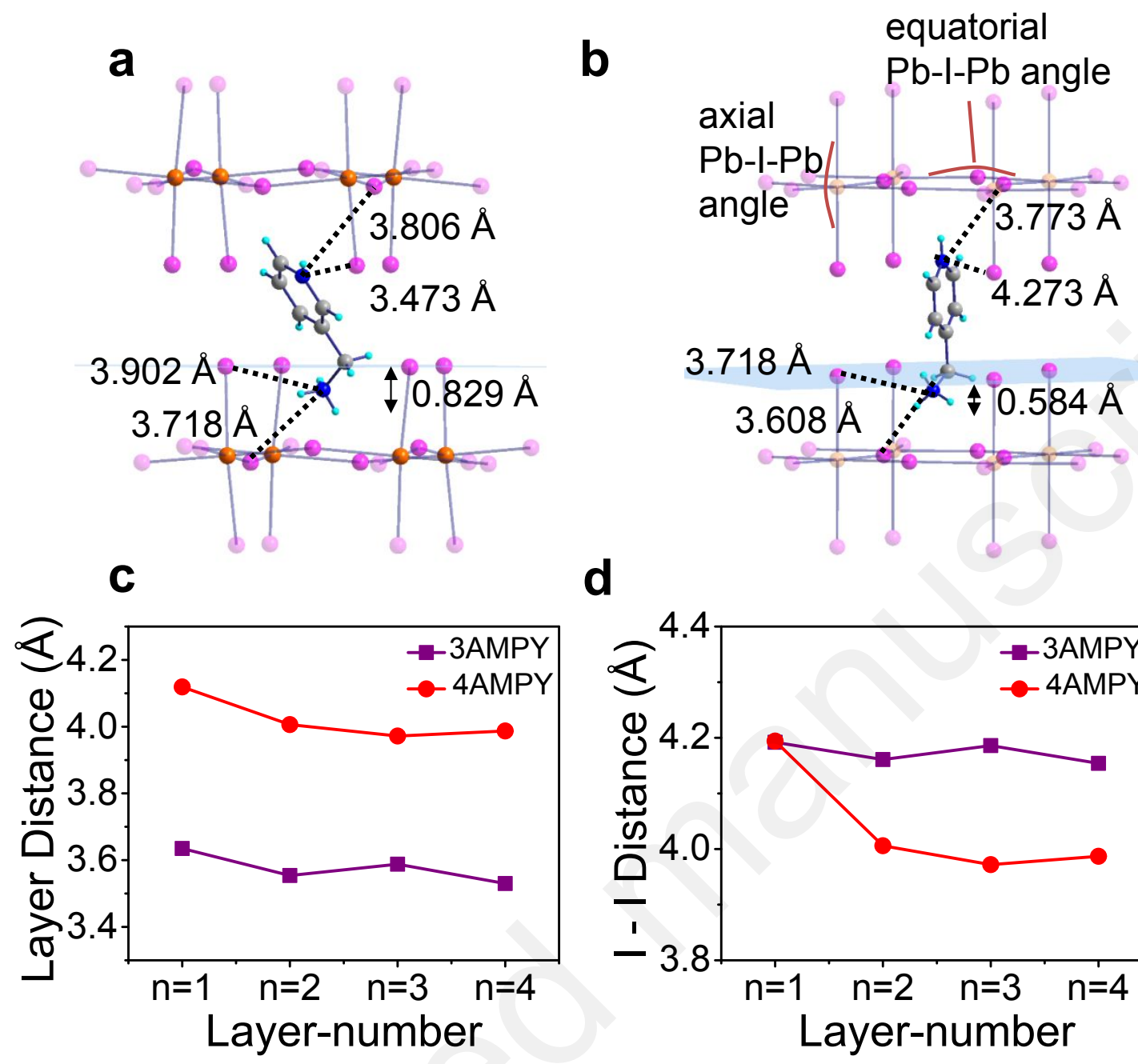

d

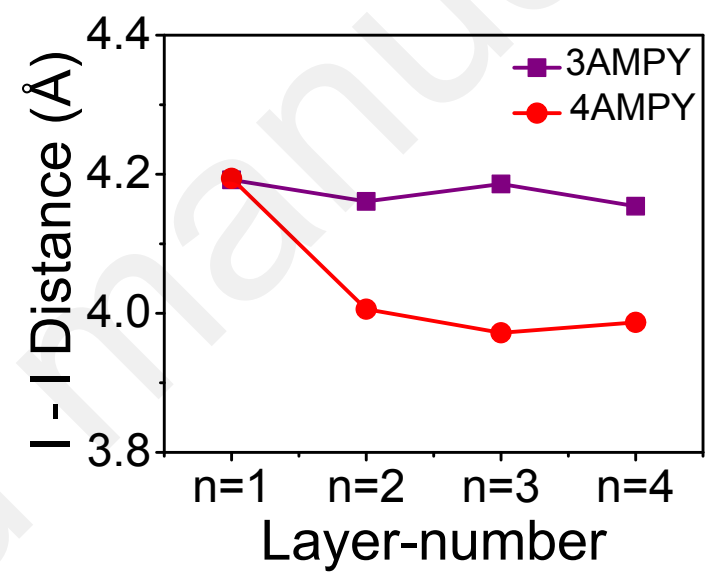

Figure 4. Structural comparison of (a) (3AMPY)(MA) $\mathrm{Pb}_{2} \mathrm{I}_{7}$ and (b) (4AMPY)(MA)Pb $\mathrm{I}_{7}$, the dash lines indicate the closest $\mathrm{NH} \cdots \mathrm{I}$ distances. (c) Interlayer distance between the planes defined by terminal iodide. (d) Closest I $\cdots$ I distance. 
a

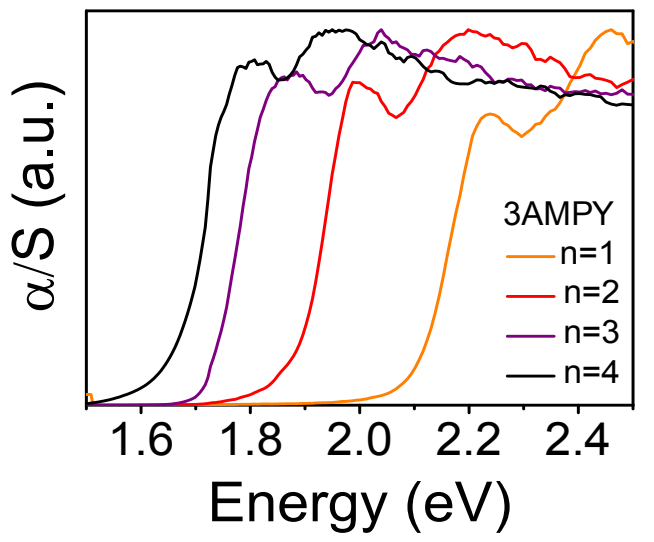

C
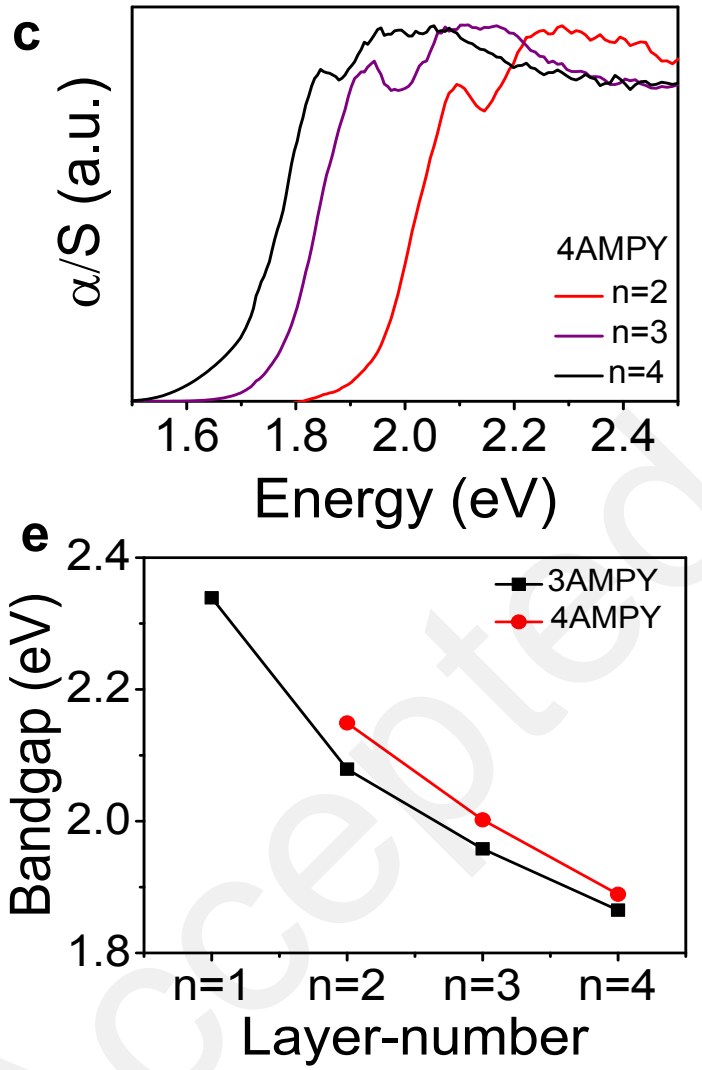

Wavelength $(\mathrm{nm})$
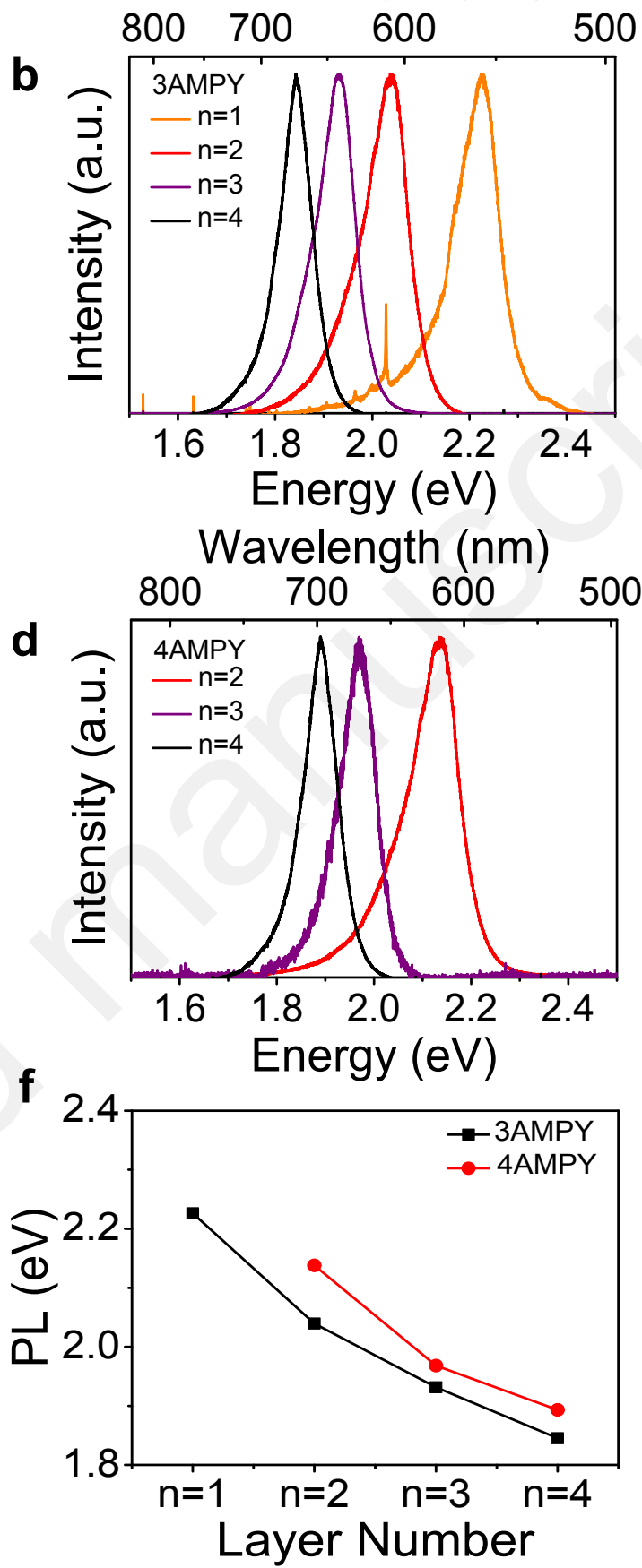

Figure 5. Comparison of optical properties of (xAMPY)(MA) $)_{n-1} \mathrm{~Pb}_{n} \mathrm{I}_{3 \mathrm{n}+1}(\mathrm{x}=3$ or $4, \mathrm{n}=1-4)$ crystals. (a,b) Optical absorption spectra and steady-state photoluminescence (PL) spectra for $(3 A M P Y)(M A)_{n-1} P b_{n} I_{3 n+1}(n=1-4)$. (c,d) Optical absorption spectra and steady-state PL spectra for $(4 A M P Y)(M A)_{n-1} P b_{n n+1}(n=2-4)$. $(e, f)$ Comparison of bandgaps and PL maximum for both series. 

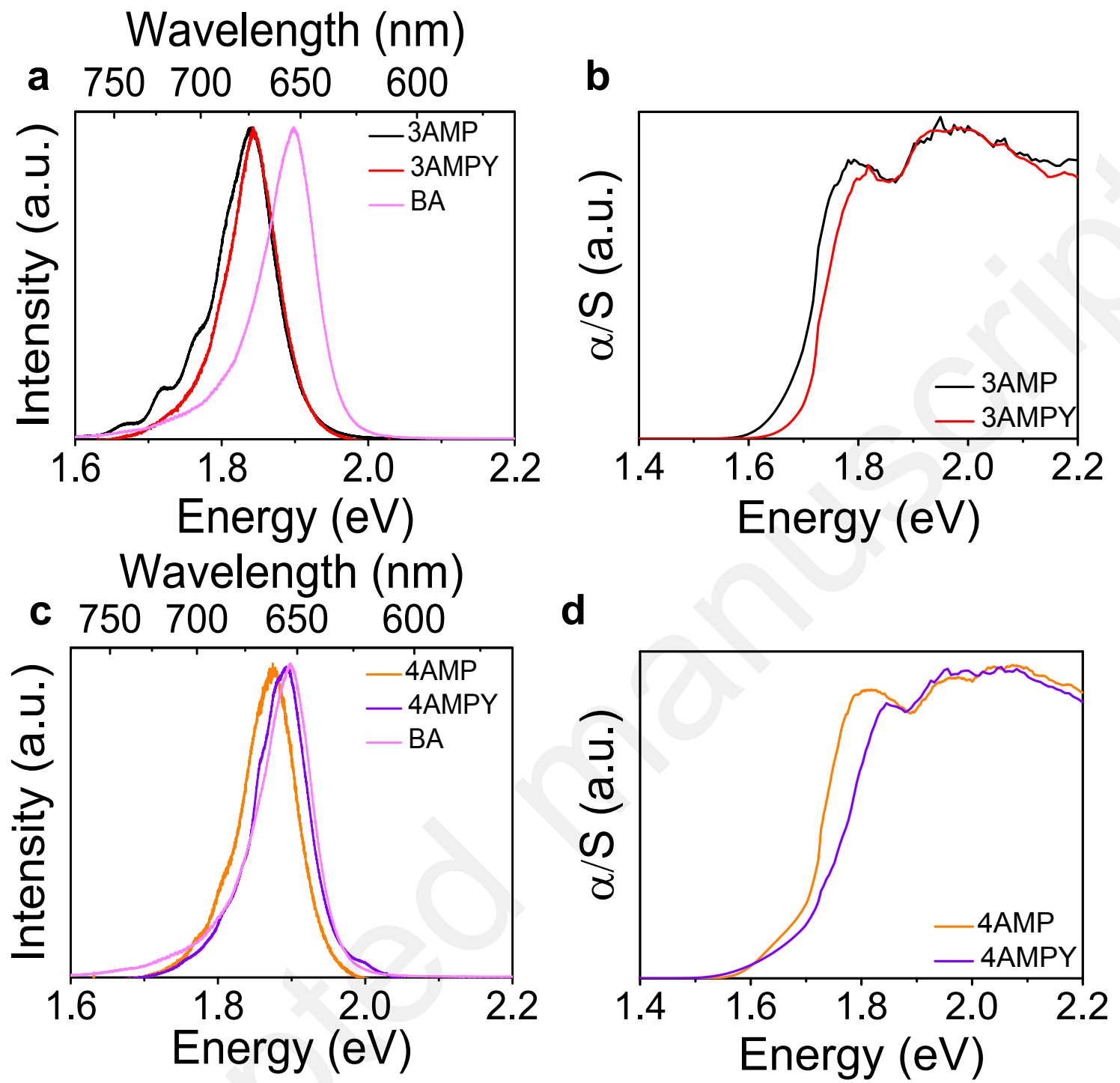

Figure 6. Comparison of PL spectra (a)(c) and absorption spectra (b)(d) for (xAMPY)(MA) $)_{3} \mathrm{~Pb}_{4} \mathrm{I}_{13}$, $(\mathrm{xAMP})(\mathrm{MA})_{3} \mathrm{~Pb}_{4} \mathrm{I}_{13}(\mathrm{x}=3,4)$ and $(\mathrm{BA})_{2}(\mathrm{MA})_{3} \mathrm{~Pb}_{4} \mathrm{I}_{13}$ crystals. 

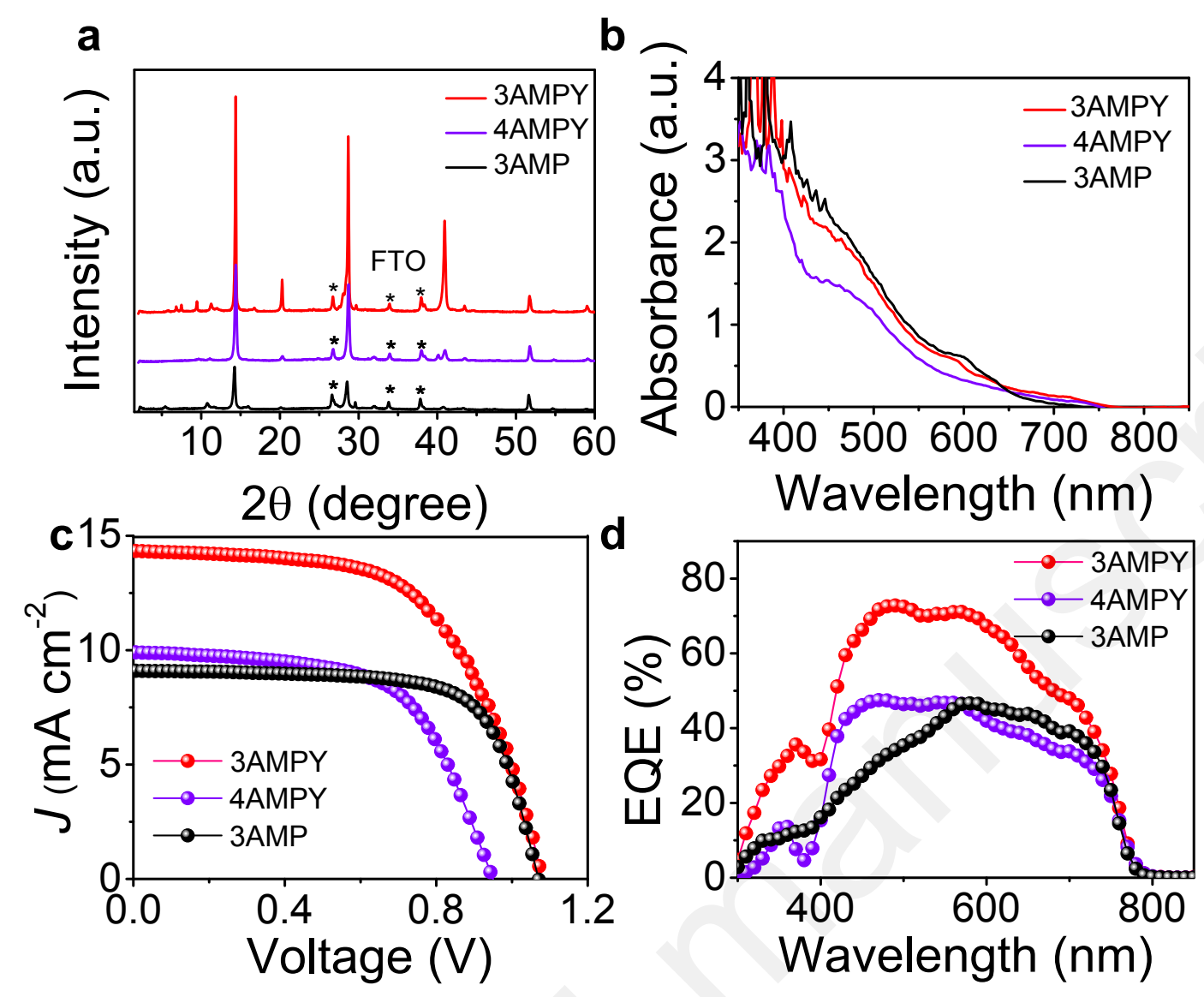

Figure 7. (a) PXRD patterns $\left(\lambda=1.5406 \AA\right.$ ) and (b) absorption spectra of (xAMPY)(MA) ${ }_{3} \mathrm{~Pb}_{4} \mathrm{I}_{13}$ $(\mathrm{x}=3$ or 4$)$ and $(3 \mathrm{AMP})(\mathrm{MA})_{3} \mathrm{~Pb}_{4} \mathrm{I}_{13}$ thin-films. (c) $J-V$ curves and (d) EQE spectra for the corresponding solar cell devices. 


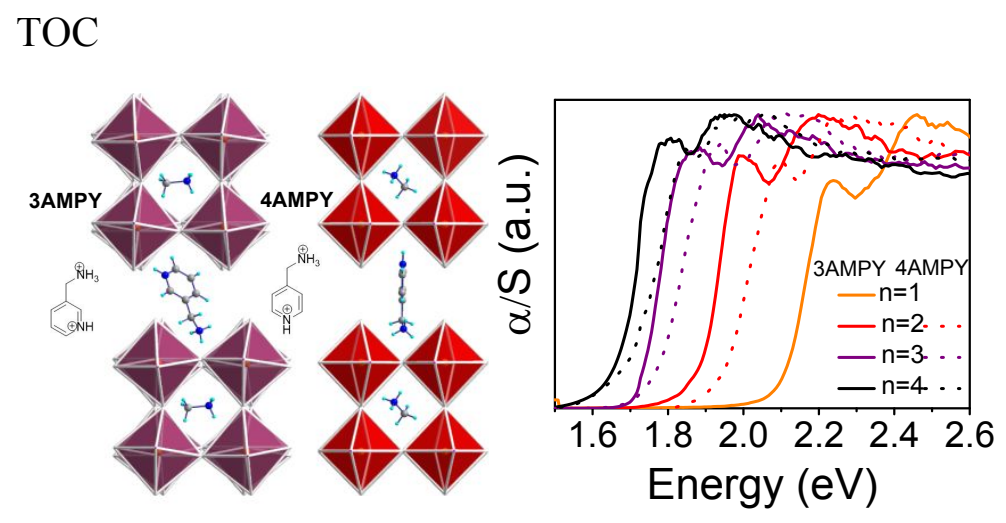

